Article

\title{
Direct Amination of Nitroquinoline Derivatives via Nucleophilic Displacement of Aromatic Hydrogen
}

\author{
Jakub Wantulok ${ }^{1}{ }^{\oplus}$, Daniel Swoboda ${ }^{1}{ }^{\oplus}$, Jacek E. Nycz ${ }^{1, *} \mathbb{D}^{\oplus}$, Maria Książek ${ }^{2}{ }^{\circledR}$, Joachim Kusz ${ }^{2}$, \\ Jan Grzegorz Małecki ${ }^{1}$ and Vladimír Kubíček ${ }^{3}$ \\ 1 Faculty of Science and Technology, Institute of Chemistry, University of Silesia in Katowice, ul. Szkolna 9, \\ PL-40007 Katowice, Poland; jakub.wantulok1@gmail.com (J.W.); daniel.swoboda@us.edu.pl (D.S.); \\ jan.malecki@us.edu.pl (J.G.M.) \\ 2 Faculty of Science and Technology, Institute of Physics, Univeristy of Silesia in Katowice, 75 Pułku Piechoty \\ 1a, 41-500 Chorzów, Poland; maria.ksiazek@us.edu.pl (M.K.); joachim.kusz@us.edu.pl (J.K.) \\ 3 Faculty of Pharmacy in Hradec Králové, Charles University Prague, Akademika Heyrovského 1203, \\ 50005 Hradec Králové, Czech Republic; kubicek@faf.cuni.cz \\ * Correspondence: jacek.nycz@us.edu.pl; Tel.: +48-32-359-1446
}

check for updates

Citation: Wantulok, J.; Swoboda, D.; Nycz, J.E.; Książek, M.; Kusz, J.; Małecki, J.G.; Kubíček, V. Direct Amination of Nitroquinoline Derivatives via Nucleophilic Displacement of Aromatic Hydrogen. Molecules 2021, 26, 1857. https:// doi.org/10.3390/molecules26071857

Academic Editor:

Nagatoshi Nishiwaki

Received: 16 February 2021

Accepted: 23 March 2021

Published: 25 March 2021

Publisher's Note: MDPI stays neutral with regard to jurisdictional claims in published maps and institutional affiliations.

Copyright: (c) 2021 by the authors. Licensee MDPI, Basel, Switzerland. This article is an open access article distributed under the terms and conditions of the Creative Commons Attribution (CC BY) license (https:// creativecommons.org/licenses/by/ $4.0 /)$.

\begin{abstract}
The vicarious nucleophilic substitution of hydrogen (VNS) reaction in electron-deficient nitroquinolines was studied. Properties of all new products have been characterized by several techniques: MS, HRMS, FTIR, GC-MS, electronic absorption spectroscopy, and multinuclear NMR. The structures of 4-chloro-8-nitroquinoline, 8-(tert-butyl)-2-methyl-5-nitroquinoline, 9-(8nitroquinolin-7-yl)-9H-carbazole and (Z)-7-(9H-carbazol-9-yl)-8-(hydroxyimino)quinolin-5( $8 H$ )-one were determined by single-crystal $X$-ray diffraction measurements. The 9-(8-nitroquinolin-7-yl)9H-carbazole and (Z)-7-(9H-carbazol-9-yl)-8-(hydroxyimino)quinolin-5(8H)-one illustrate the nitro/nitroso conversion within VNS reaction. Additionally, 9-(8-isopropyl-2-((8-isopropyl-2-methyl5-nitroquinolin-6-yl)methyl)-5-nitrosoquinolin-6-yl)-9H-carbazole is presented as a double VNS product. It is postulated that the potassium counterion interacts with the oxygen on the nitro group, which could influence nucleophile attack in that way.
\end{abstract}

Keywords: amination; vicarious nucleophilic substitution of hydrogen; nucleophilic aromatic substitution $\left(\mathrm{S}_{\mathrm{N}} \mathrm{Ar}\right)$; nitration; heterocyclic; Skraup; Meldrum's acid

\section{Introduction}

The worldwide annual production of quinoline derivatives is more than 2000 tonnes, of which 8-hydroxyquinoline makes up the main part [1]. The amino group is the essential building block of many molecules found in nature, e.g., peptides and proteins. Introducing this moiety into molecular structures is a crucial process, no matter the scale of the reaction and the purpose of the application. To explore the structure-function relationship of biologically active quinoline compounds, such as their coordination metal ability, the study of amination of nitroquinoline derivatives was carried out in our laboratory. This research focuses on the vicarious nucleophilic substitution of hydrogen (VNS). Recently, the amination reactions of 4,7-dichloro-1,10-phenanthrolines using bulky $9 H$-carbazole, $10 \mathrm{H}$-phenothiazine, and pyrrolidine nucleophiles were reported by our group [2]. The targeted compounds obtained were exclusively 4,7-diamino-1,10-phenanthrolines with yields up to $96 \%$ [2]. Two fully characterized products of a similar chemical transformation, the oxidative nucleophilic substitution of hydrogen (ONSH), were presented (Figure 1) [2]. 


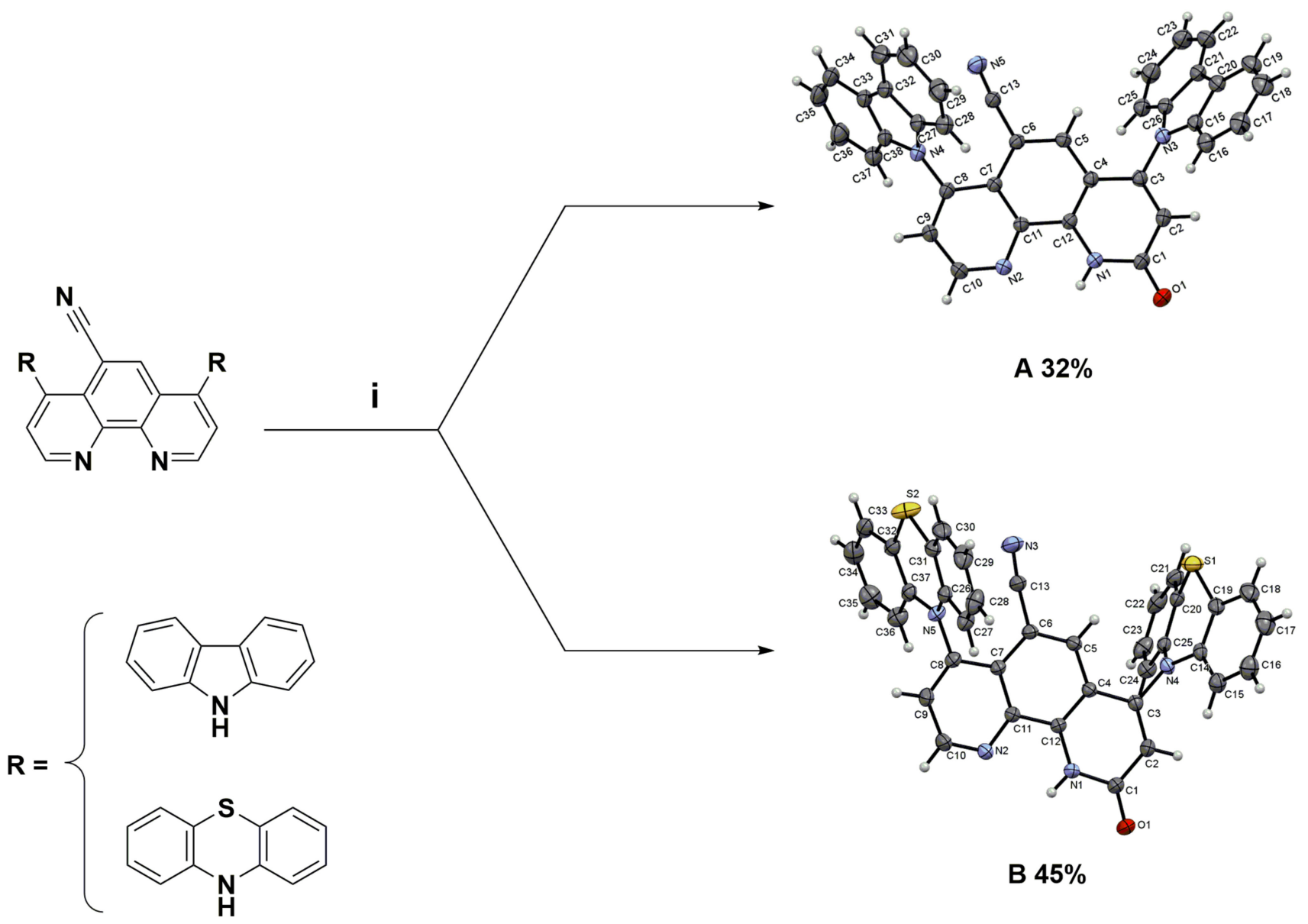

Figure 1. Structural formula of 4,7-di(9H-carbazol-9-yl)-9-oxo-9,10-dihydro-1,10-phenanthroline-5-carbonitrile (A) and 2-oxo-4,7-di(10H-phenothiazin-10-yl)-1,2-dihydro-1,10-phenanthroline-5-carbonitrile (B). Reagents and conditions: (i) $10 \%$ $\mathrm{NaOH}$, tetrahydrofuran (THF), $60{ }^{\circ} \mathrm{C}, 4$ days [2].

Both reactions, VNS and ONSH, proceed via the initial addition of nucleophile to the nitroaromatics and heteroaromatics to form a sigma-complex type intermediate. Then spontaneous oxidation of intermediate sigma-complex by oxidizing agents produces final products. The advantage of these methods is the aromatic functionalization with no need for halogenated materials or expensive metal catalysts. The work of Prof. Makosza and co-workers inspired us to perform our investigations [3].

\section{Results and Discussion}

In the current study, we present the amination procedures of selected nitroquinoline derivatives.

\subsection{Synthesis of Nitroquinoline Derivatives}

In order to synthesize nitroquinoline derivatives as the precursors of the target aminoquinolines, two types of chemical transformations were applied. One was based on the classical Skraup-Doebner-Miller reaction and a three-step cyclocondensation of 2,2-dimethyl1,3-dioxane-4,6-dione (Meldrum's acid), trimethyl orthoformate, and 2-nitroaniline (molecule $4 \mathbf{b})$. The synthetic routes and their structures are presented in Scheme 1. In the second route, we chose the direct nitration of selected 8-(alkyl)-2-methylquinolines (molecules 3c and 3d), which was a one-step method to introduce carbon-nitrogen bond and requires higher electron density in benzene (or phenol) rings as described earlier [4]. The nitration of hydroxyquinoline derivatives occurs at low temperatures ca. $5{ }^{\circ} \mathrm{C}$ due to the hydroxyl group's strong activating effect. In comparison, the syntheses of nitroquinolines $4 \mathbf{c}$ and $\mathbf{4 d}$ 
required a temperature of at least $70{ }^{\circ} \mathrm{C}$ and took more than $16 \mathrm{~h}$ to complete. In all cases, reactions were selective and occurred with high yields, up to $94 \%$ (Scheme 1).
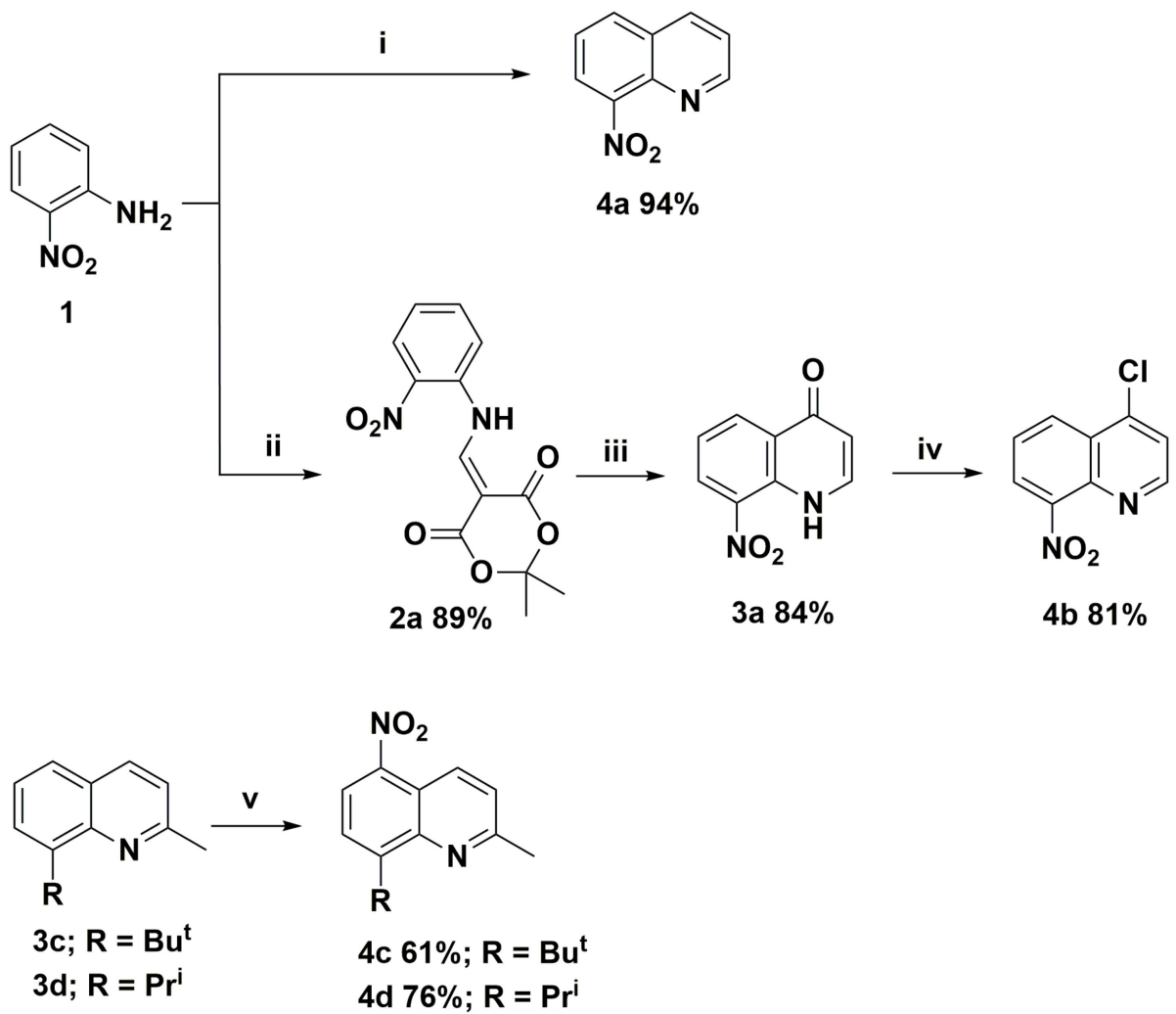

Scheme 1. Synthesis routes of nitroquinoline derivatives 4; Reagents and conditions: (i) acrolein, $6 \mathrm{M} \mathrm{HCl}$; (ii) Meldrum's acid, trimethyl orthoformate; (iii) $\mathrm{Ph}_{2} \mathrm{O} \mathrm{T}=240{ }^{\circ} \mathrm{C}$; (iv) $\mathrm{Cl}_{3} \mathrm{P}(=\mathrm{O}$ ); and (v) $\mathrm{H}_{2} \mathrm{SO}_{4}, \mathrm{HNO}_{3} \mathrm{~T}>70{ }^{\circ} \mathrm{C}$.

The presented nitroquinoline derivatives 4 are compounds that have easily formed crystals (Figures 2 and 3).
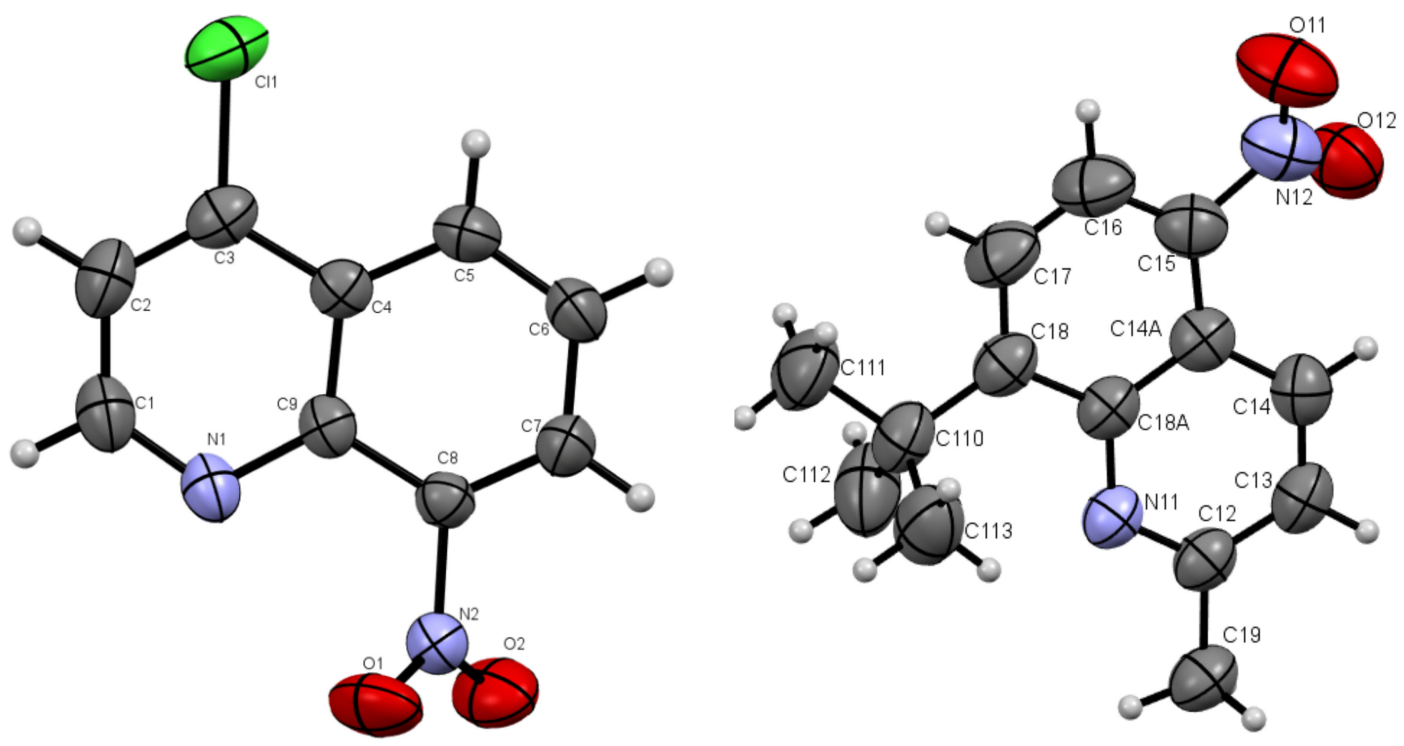

Figure 2. Oak Ridge Thermal Ellipsoid Plot (ORTEP) drawings of compound $4 \mathbf{b}$ with 50\% probability (left). 4c with $50 \%$ probability (right). 


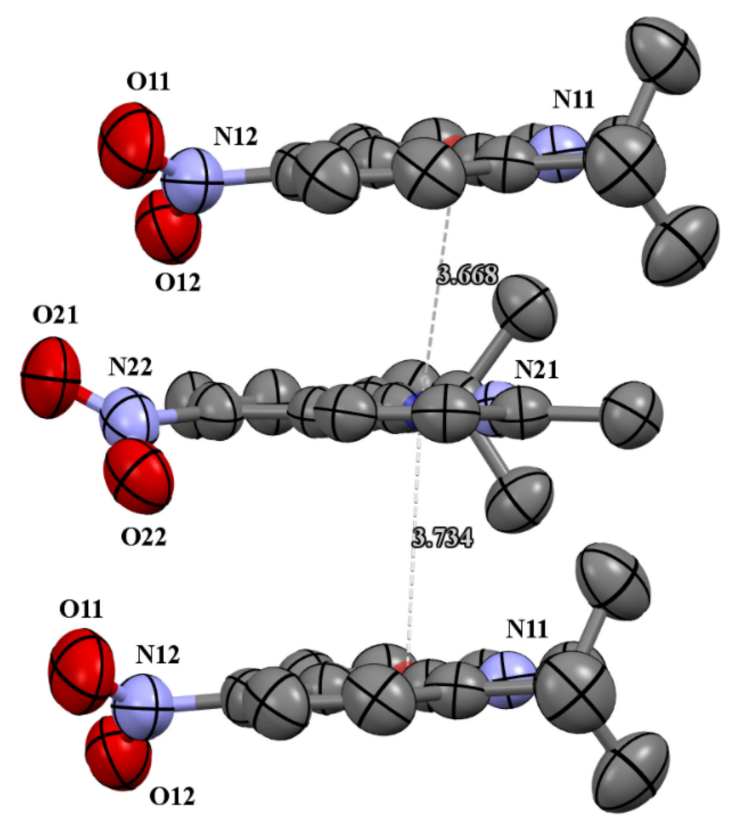

Figure 3. The $\pi$-stacking interactions in cell packing of compound 4c.

\subsection{X-ray Studies of Nitroquinolines}

The molecules $4 \mathbf{b}$ and $4 \mathrm{c}$ crystallized in orthorhombic $P$ bc21 and monoclinic $P 21 / \mathrm{c}$ space groups, respectively. Their molecular structures are displayed as ORTEP representations in Figure 2. The compounds $\mathbf{4 b}$ and $\mathbf{4 c}$ are planar. As one can see from Figure 3, the compound $4 \mathrm{c}$ has two independent molecules in the asymmetric unit. The structure of the presented molecule $4 \mathrm{c}$ is stabilized by $\pi-\pi$ stacking interactions, which occur between quinoline rings (Figure 3). The centroid-centroid distances vary from 3.668-3.734 $\AA$, and the shift distances are between 1.233-1.464 A.

Additional bond lengths and angles and crystallographic refinement details can be found in Table S1 from Supplementary Materials.

\subsection{Amination of Nitroquinoline Derivatives via Vicarious Nucleophilic Substitution of Hydrogen}

Crystalline nitroquinoline derivatives $4 \mathbf{a}, \mathbf{4 b}$, and $\mathbf{4 d}$ with the presence of hindered and non-hindered hydrogens in ortho and/or para positions were chosen in our studies. The readily available aromatic hydrogen located in ortho and/or para position to the nitro group is the main requirement for the vicarious nucleophilic substitution from the starting material. The nitro group activates an aromatic ring to nucleophilic attack. Nucleophilic addition to carbon atoms of the nitroaromatics and heteroaromatics is a fast and reversible process [3], during which negatively charged intermediates are created, i.e., the Meisenheimer complex (Scheme 2), with the stabilization of substituents via the delocalization of charge. Therefore, electron-withdrawing (EW)-type substituents, especially the nitro group, are needed. The nucleophile's counterion, such as potassium cation, is attracted by the nitro group's negatively charged oxygen atoms (Scheme 2). The resulting adducts to restore the aromaticity have to lose hydride anions (Scheme 2). This process could be realized by oxidation by external oxidants. N. J. Lawrence et al. suggests that the nitro group also plays a role in the oxidation processes [5]. It is essential to mention that VNS reaction may compete with the aromatic nucleophilic substitution of halogen $S_{N} A r$. The substitution of the nitro substituent is also possible. According to Makosza et al., the VNS often proceeds much faster than substitutions, as mentioned above $[3,5,6]$. The VNS reaction is usually highly colored, which has diagnostic values [3]. However, some exceptions could be seen in literature, such as 4-fluoro-5-nitropyridine, which participates exclusively in the aromatic nucleophilic substitution of halogen $S_{N} A r$ [7]. 


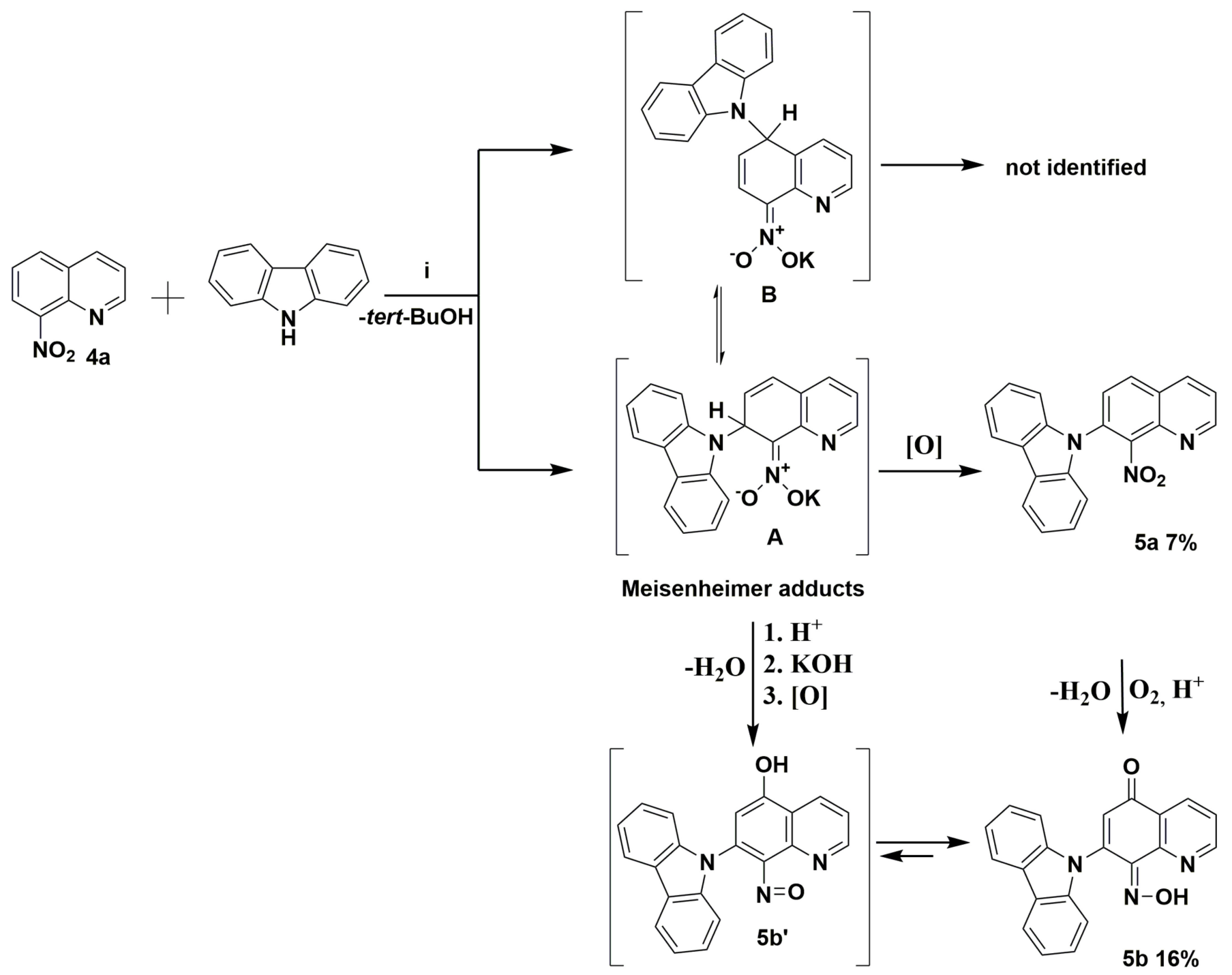

Scheme 2. Proposed mechanism of the reaction between the potassium carbazol-9-ide and nitroquinoline 4a. Reagents and conditions: (i) $9 \mathrm{H}$-carbazole, tert-BuOK, THF, and reflux.

In our studies, as a nucleophile, $9 H$-carbazole was chosen to compare our recent results from the amination reactions of 4,7-dichloro-1,10-phenanthrolines [2]. 9H-Carbazole has a special rigid planar structure and is a valuable building block for the synthesis of many products like drugs or innovative materials.

The commercially available quinolone $4 \mathbf{a}$ and $9 \mathrm{H}$-carbazole were initially selected to carry out the reaction to ascertain the mechanism and optimize conditions. According to previously reported data, the reaction of molecule $4 \mathbf{a}$ was carried out with an excess (1.5 equiv.) of potassium $9 \mathrm{H}$-carbazol-9-ide in THF solvent, which quickly turned red, at reflux temperature according to previously reported data $[2,8]$. Crystalline 9-(8-nitroquinolin7-yl)-9H-carbazole (5a) and (Z)-7-(9H-carbazol-9-yl)-8-(hydroxyimino)quinolin-5(8H)-one (5b) were isolated with low yield (Scheme 2, and Figures 4 and 5). At first sight, it is somewhat surprising that the vicarious nucleophilic substitution via nucleophilic displacement of aromatic hydrogen of molecule 4 a led to two products, both with $9 \mathrm{H}$-carbazolyl group located exclusively at the $\mathrm{C} 7$ position. The regiochemistry of this type of substitution is strongly affected by the size of the nucleophile. Because of the bulky nucleophile used, it was expected that a newly formed $\mathrm{C}-\mathrm{N}$ bond will be formed rather in $\mathrm{C} 5$ position than $\mathrm{C}$. This finding suggests the potassium counterion assists the interaction with the nitro group. A nucleophile's attack generates a Meisenheimer adduct $\left(\sigma^{\mathrm{H}}\right.$-adduct) followed by a loss of 
hydrogen to restore the aromaticity (Scheme 2). The molecule 5a possesses at $\mathrm{C7}$ position a newly-attached $9 \mathrm{H}$-carbazolyl substituent in ortho location to nitro group (Scheme 2). The molecule $\mathbf{5} \mathbf{b}^{\prime}$ contains a hydroxyl group at $\mathrm{C} 5$ and nitroso substituent at $\mathrm{C} 8$ position. The conversion of nitro to nitroso group is known in literature [3,9]. In our research to generate potassium carbazol-9-ide in THF, potassium tert-butoxide and $9 \mathrm{H}$-carbazole were chosen. The in-situ-generated tert-BuOH serves as a proton source (Scheme 2; step 1). The nitro group at the $\mathrm{C} 8$ position in molecule $\mathbf{5 a}$ or Meisenheimer adduct in protic media could be transformed into nitroso by protonation and the subsequent elimination of a water. The origin of compound $\mathbf{5} \mathbf{b}^{\prime}$ requires both the transformation of the nitro group into nitroso and the presence of hydroxyl substituent (or carbonyl) at C5 position. One explanation of the origin of the $5 \mathbf{b}^{\prime}$ could be the displacement of the potassium hydroxide from the Meisenheimer adduct in protic media (Scheme 2; step 2). The potassium hydroxide could attack Meisenheimer's nitrosophenyl ring at C5 position and form a hydroxyl group in nitroso adduct, followed by oxidation by oxygen from the air or nitro substituent to a carbonyl group (Scheme 2; step 3). T. N. Gurova et al. showed the influence of substituents and medium on the tautomeric equilibrium between nitrosophenols and quinone oximes [10]. Another similar phenomenon is reported by I. R. Baxendale et al. [11]. We report a similar type of phenomenon between the nitroso adduct $5 \mathbf{b}^{\prime}$ and molecule $5 \mathbf{b}$ (Scheme 2).

We already mentioned that VNS reaction might compete with the aromatic nucleophilic substitution of halogen $\mathrm{S}_{\mathrm{N}} \mathrm{Ar}$. In order to verify this thesis in the subsequent reaction, quinolone $4 \mathrm{~b}$ with chloride atom located in activated $\mathrm{C} 4$ position was selected. The reaction was carried out with the same condition as previously reported. Our results showed that the direct nucleophilic displacement of an aromatic hydrogen reaction proceeds together with expected aromatic nucleophilic substitution of halogen $S_{N} A r$. The reaction mixture was very complicated. However, we were able to identify the product similar to $9,9^{\prime}$-(8nitroquinoline-4,7-diyl)bis(9H-carbazole) (5c) as a result of VNS and $\mathrm{S}_{\mathrm{N}} \mathrm{Ar}$ subsequent substitutions. GC-MS's identified product is with $\mathrm{tr}=27.3 \mathrm{~min},(\mathrm{EI}) \mathrm{M}^{+}=508(100 \%)$, whose structure is similar to molecule $5 \mathrm{c}$ and has an exact mass is 504 (Figure S7 from Supplementary Materials, Scheme 3).

The $\mathrm{N}-\mathrm{C}_{\text {Aryl }}$ bond formation via VNS reaction in 2-methylquinoline derivatives such as molecule $4 \mathbf{d}$ is more complicated due to the acidic protons located on the methyl group $\mathrm{C} 2$ position [12]. Their presence in the quinoline constitution implicates a competition reaction between VNS N-C Aryl bond formation and a base attack at acidic protons located on the methyl group in C2 position. To synthesize the targeted 9-(8-isopropyl-2-methyl5-nitrosoquinolin-6-yl)-9H-carbazole (VNS product; Scheme 3), a reaction was carried out where molecule $4 \mathbf{d}$ was treated with excess (1.5 equiv.) potassium $9 H$-carbazol-9-ide in THF solvent at reflux temperature under the same reaction conditions as the above example. Molecule $4 \mathbf{d}$ was chosen due to the presence of an easier diagnostic iso-propyl group. Unexpectedly a product of double VNS substitution 9-(8-isopropyl-2-((8-isopropyl2-methyl-5-nitroquinolin-6-yl)methyl)-5-nitrosoquinolin-6-yl)-9H-carbazole (5d) was obtained. The formation of nitroso adduct observed was possible by elimination of a water molecule, which is similar to the aforementioned mechanism of origin of $5 \mathbf{b}^{\prime}$ (Scheme 2). The origin of molecule $\mathbf{5} \mathbf{d}$ can be explained by potassiation with potassium tert-butoxide followed by an intramolecular transfer of the 8-iso-propyl-2-methyl-5-nitroquinoline, which afforded molecule $5 \mathbf{d}$ in $44 \%$ yield (Scheme 3). N. J. Lawrence et al. reported VNS reaction product as an intermediate react with various electrophiles [5]. 

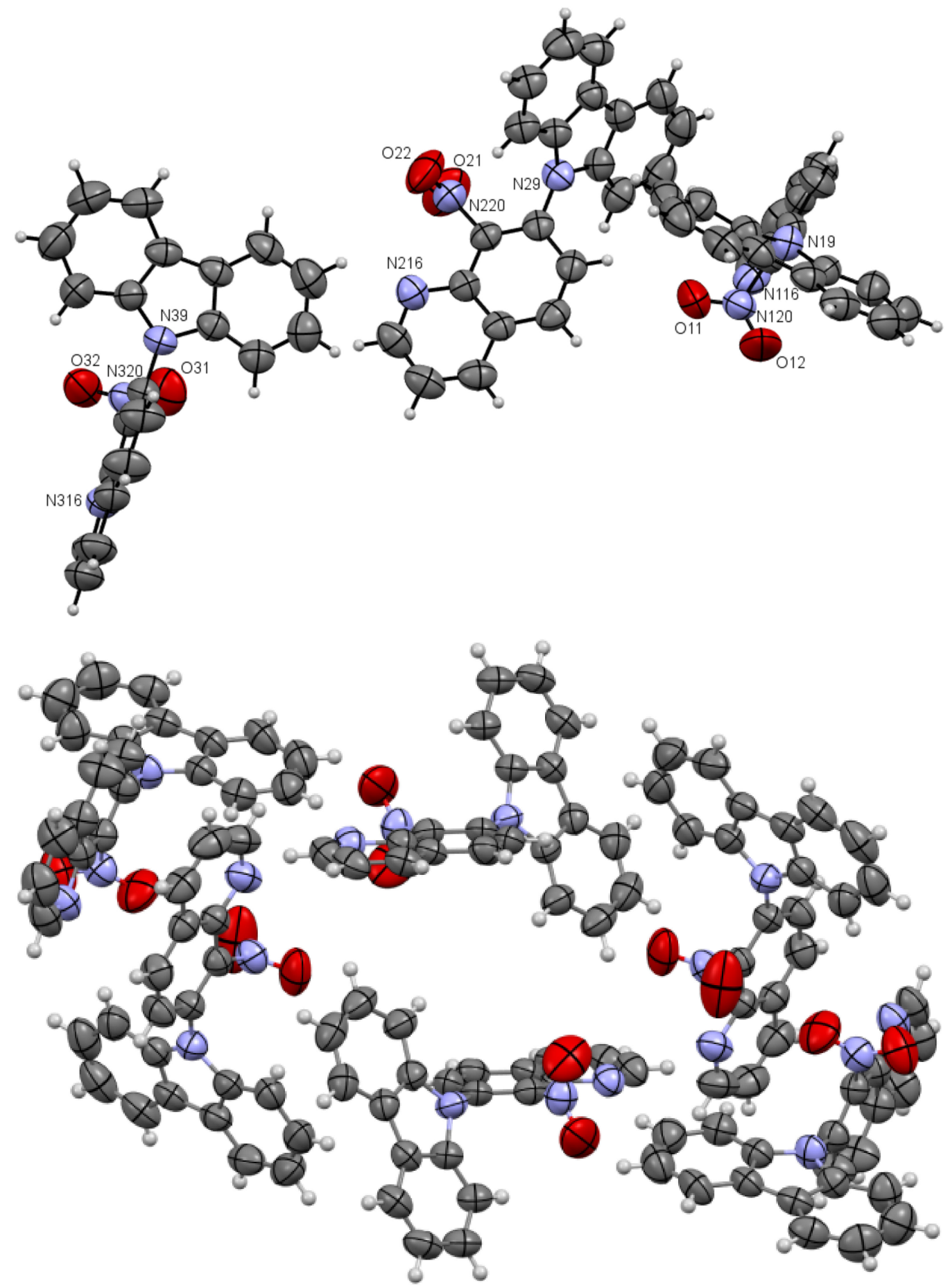

Figure 4. ORTEP drawings of compound 5a with 50\% probability (upper). ORTEP drawings of packing of compound 5a with $50 \%$ probability (below). 

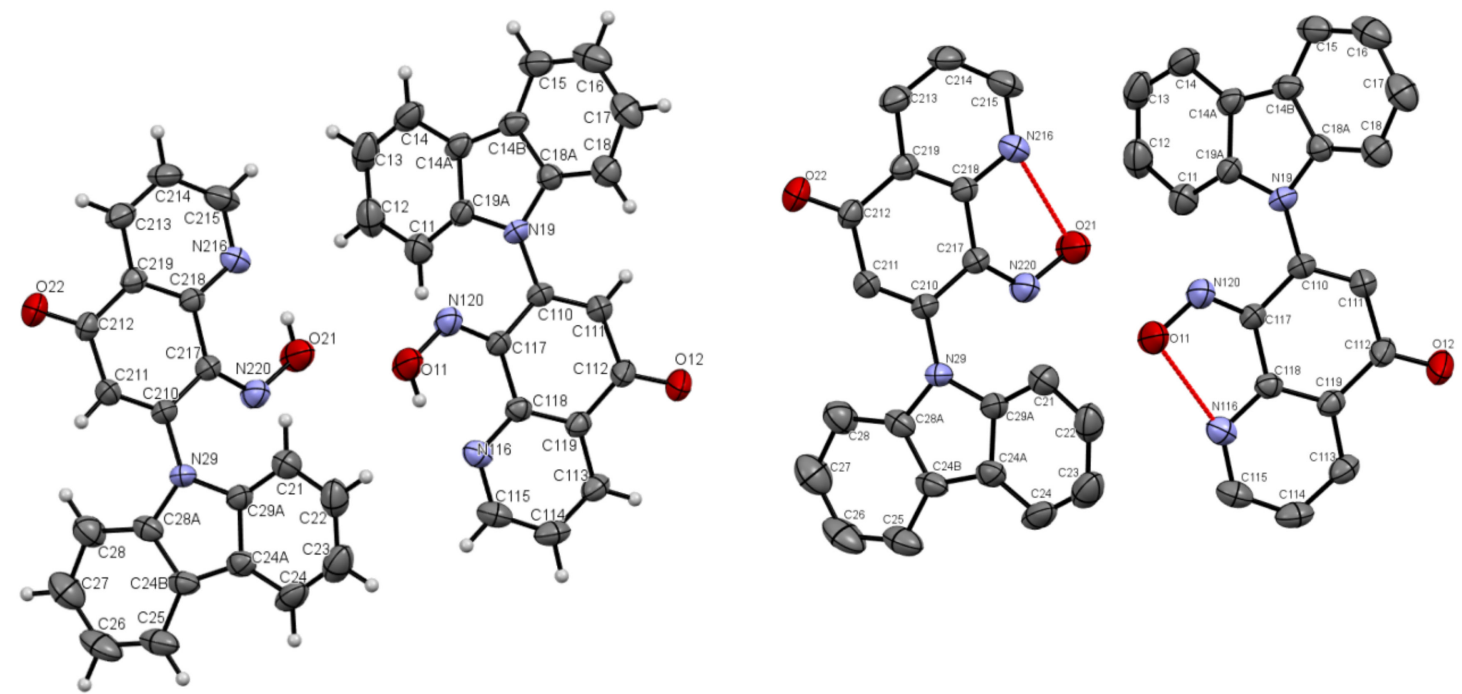

Figure 5. ORTEP drawings of compound $5 \mathrm{~b}$ with $30 \%$ probability (left). ORTEP drawings of compound $5 \mathrm{~b}$ with $30 \%$ probability with hydrogen bonds (right).<smiles>O=[N+]([O-])c1cccc2c(Cl)ccnc12</smiles>

$4 b$<smiles>O=[N+]([O-])c1c(-n2c3ccccc3c3ccccc32)ccc2c(-n3c4ccccc4c4ccccc43)ccnc12</smiles>

5 c<smiles>c1ccc2c(c1)[nH]c1ccccc12</smiles>

N<smiles>Cc1ccc2c([N+](=O)[O-])c(Cc3ccc4c(N=O)c(C)cc(C(C)C)c4n3)cc(C(C)C)c2n1</smiles>

$5 d 44 \%$

Scheme 3. The reaction between the potassium carbazol-9-ide and nitroquinolines $4 \mathbf{b}$ and $4 \mathrm{~d}$. Reagents and conditions: (i) $9 \mathrm{H}$-carbazole, tert-BuOK, THF, reflux.

As one can see from Figure 4, the compound $\mathbf{5 a}$ has three independent molecules in the asymmetric unit and molecule $\mathbf{5 b}$ two in Figure 5. Selected bond lengths ( $(\AA)$ and angles $\left({ }^{\circ}\right)$ for $\mathbf{5 a}$ are collected in Table S2 from Supplementary Materials.

A characteristic feature in ${ }^{1} \mathrm{H}-\mathrm{NMR}$ spectra of molecule $5 \mathbf{b}$ with hydroxyimino group that was acquired in dimethyl sulfoxide (DMSO) solvent was the pronounced downfield shift of $\mathrm{OH}$ proton signal (17.41 ppm), pointing to a strong intramolecular $\mathrm{N} \cdots \mathrm{HO}-\mathrm{N}$ 
hydrogen bond. The same $\mathrm{OH}$ proton signal was moved to $17.76 \mathrm{ppm}$ in $\mathrm{CDCl}_{3}$ solvent. The explanation of this phenomenon is the ability to form a pseudo-ring by molecule $\mathbf{5 b}$, stabilized by intramolecular hydrogen bond in the DMSO or $\mathrm{CDCl}_{3}$ solvent (see Scheme 2, Figure 5). The structure of compound $\mathbf{5} \mathbf{b}$ confirmed by $\mathrm{X}$-ray structural analysis showed strong intramolecular N...HO-N hydrogen bonds, which are listed in Table 1. Selected bond lengths $(\AA)$ and angles $\left({ }^{\circ}\right)$ for $\mathbf{5 b}$ are collected in Table S3 from Supplementary Materials.

Table 1. Hydrogen bonds for $\mathbf{5 b}$.

\begin{tabular}{|c|c|c|c|c|}
\hline$D-\mathbf{H} \cdots A$ & $D-\mathrm{H}(\AA ̊)$ & $\mathrm{H} \cdots A(\AA)$ & $D \cdots A(\AA)$ & $D-\mathrm{H}^{\prime} \cdots A\left(^{\circ}\right)$ \\
\hline 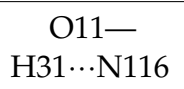 & 0.82 & 1.80 & $2.548(4)$ & 150.6 \\
\hline $\begin{array}{c}\mathrm{C} 111- \\
\mathrm{H} 111 \cdots \mathrm{O} 22^{\mathrm{i}}\end{array}$ & 0.93 & 2.50 & $3.382(4)$ & 158.3 \\
\hline $\begin{array}{c}\mathrm{O} 21- \\
\mathrm{H} 41 \cdots \mathrm{N} 216\end{array}$ & 0.82 & 1.78 & $2.533(4)$ & 151.0 \\
\hline $\begin{array}{c}\mathrm{C} 211- \\
\mathrm{H} 211 \cdots \mathrm{O} 12^{\mathrm{ii}}\end{array}$ & 0.93 & 2.44 & $3.311(4)$ & 156.8 \\
\hline
\end{tabular}

Symmetry transformation used to generate equivalent atoms: (i) $-x,-y+1, z+1 / 2$; (ii) $-x+1 / 2, y+1 / 2, z-$ $1 / 2$.

The molecules $\mathbf{5} \mathbf{a}$ and $\mathbf{5 b}$ were crystallized in triclinic $P-1$ and orthorhombic $P$ na21 space groups, respectively. Their molecular structures are displayed as ORTEP representations in Figures 4 and 5 in planar orientation. In Figure 4, compound 5a has three, and compound $\mathbf{5 b}$ has two independent molecules in the asymmetric unit (Figure 5). The structure of molecule $\mathbf{5 b}$ is stabilized by strong intramolecular $\mathrm{N} \cdots \mathrm{HO}-\mathrm{N}$ hydrogen bonds (Table 1, Figure 5 ) and $\pi-\pi$ stacking interactions, which occurs between quinoline rings (Figure 6). The centroid-centroid distances vary from 3.586-3.642 $\AA$, and the shift distances are between $0.206-1.050 \AA$ (Figure 6).

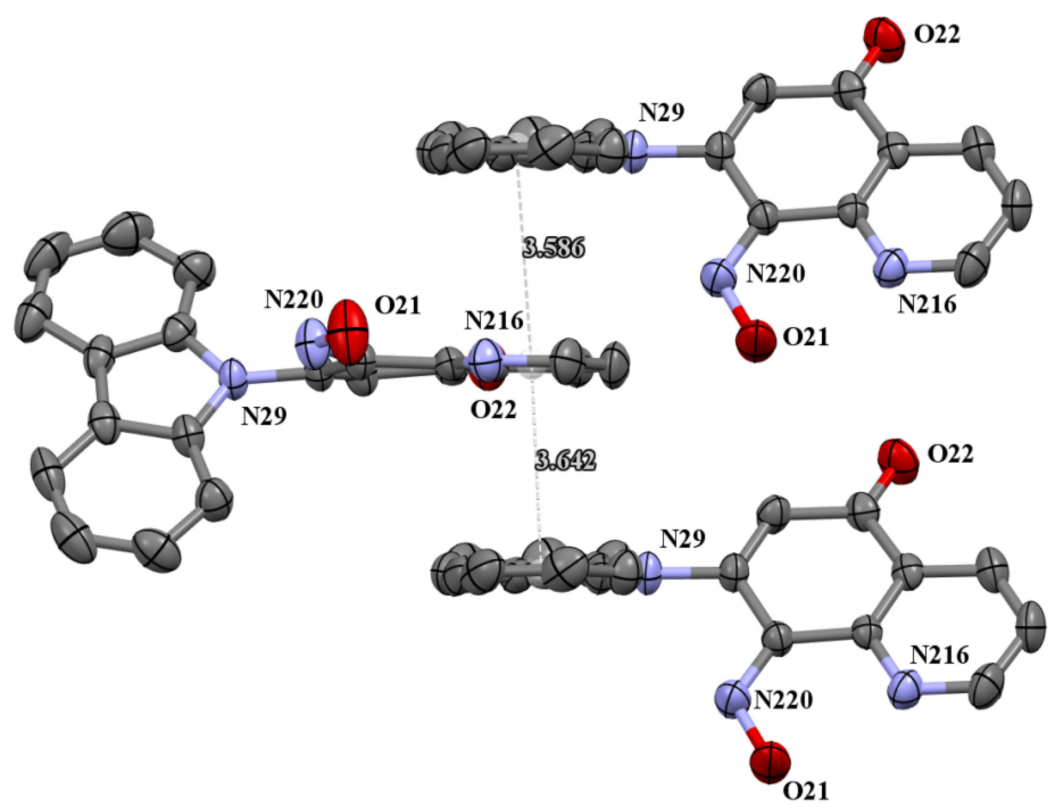

Figure 6 . The $\pi$-stacking interactions in cell packing of compound $5 \mathbf{b}$.

Compounds $\mathbf{5} \mathbf{a}$ and $\mathbf{5 b}$ are composed of an 8-nitroquinoline core in a planar orientation and peripheral amino substituent. The $9 \mathrm{H}$-carbazol-9-yl substituent is strongly twisted in relation to the quinoline rings with a larger angle $\left(86.43^{\circ}, 84.98^{\circ}, 67.96^{\circ}\right)$ for $5 \mathbf{a}$ and $\left(\sim 54.73^{\circ}\right)$ for $5 \mathbf{b}$ between quinoline and $9 \mathrm{H}$-carbazol-9-yl substituent planes in the position C7. It is worth noting that bond lengths between the carbon atom at C7 position 
in the quinoline moiety and nitrogen atom in $9 H$-carbazol-9-yl substituent are $\sim 1.42 \AA$ and are comparable to the values of $1.42 \AA$ in 4,7-di(9H-carbazol-9-yl)-9-oxo-9,10-dihydro-1,10phenanthroline-5-carbonitrile [2].

\subsection{UV-Vis Studies for Molecule $\mathbf{5 b}$}

Our studies were performed by varying $\mathrm{pH}$ and solvent to examine their effect on the absorbance of molecule $\mathbf{5 b}$ (Figure 7). Compound $\mathbf{5 b}$ shows the ability to form a pseudoring, stabilized by an intramolecular hydrogen bond in solution, shown on ${ }^{1} \mathrm{H}-\mathrm{NMR}$ spectra as a signal from $\mathrm{OH}$ group (in $\mathrm{CDCl}_{3}$ solution $17.76 \mathrm{ppm}$ ). The phenomenon of forming a pseudo-ring, which was stabilized by intramolecular hydrogen bond, was also observed before by our group [13]. Additionally, the tautomerism between nitrosophenol $\mathbf{5} \mathbf{b}^{\prime}$ and quinine oxime $\mathbf{5 b}$ forms presented in Scheme 2 could have an influence on absorption spectra. In Figure 7 we present the graph confirming the presence of a pure anionic form of nitrosophenol $\mathbf{5} \mathbf{b}^{\prime}$ in $1 \mathrm{M} \mathrm{KOH}$ solution for studied molecule $\mathbf{5 b}$ (black line). The similar tendency was observed for $\mathbf{5} \mathbf{b}$ in dimethylformamide (DMF) solvent (red line). The $\lambda_{\max }$ value of compound $\mathbf{5 b}$ in methanol in comparison with $\mathrm{KOH}$ and DMF solutions showed bathochromic shift (red shift), which could be explained by the presence of hydrogen bonds between quinine oxime $\mathbf{5 b}$ and methanol molecules (green dots). As expected, the increase of the number of hydrogen bonds between solute and more acidic $\mathrm{CHCl}_{3}$ leads to an increase in the wavelength of the absorption maxima of compound $\mathbf{5 b}$, which shifts bathochromically (blue intermittent line). The neutral DMSO and acetonitrile (ACN) solvents showed intermediate results. We observed longer wavelengths (bathochromic shift) with a decrease of dielectric constant in the absorption band. Additionally, the dielectric dependence on the wavelength was presented in Figure 7.
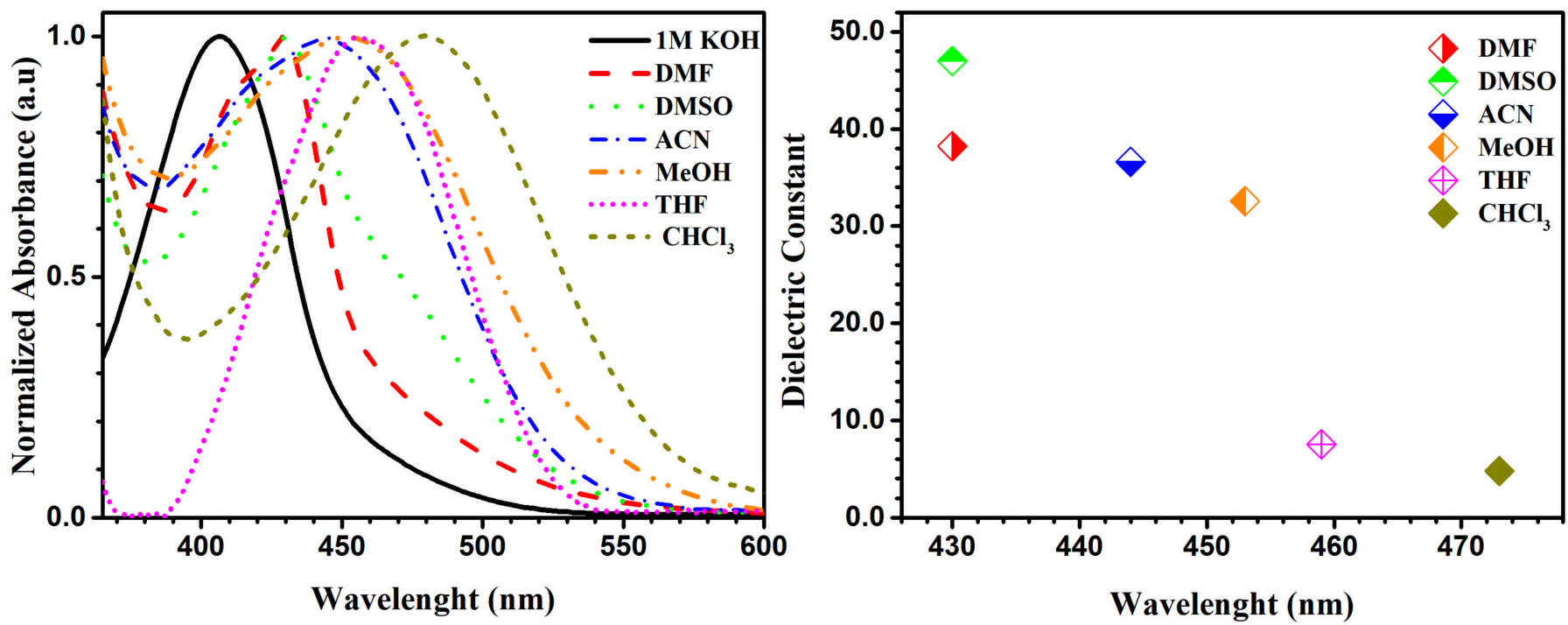

Figure 7. UV-Vis absorption spectra (left), plot of the dielectric constant of solvent against wavelength of $5 \mathbf{b}$ (right).

In the ${ }^{1} \mathrm{H}-\mathrm{NMR}$ spectra in $\mathrm{DMSO}$ and $\mathrm{CDCl}_{3}$ polar solvents, we observed only nitroso form $\mathbf{5 b}$. However, after the addition of a drop of KOD solution of $\mathrm{D}_{2} \mathrm{O}$ to DMSO solvent in the ${ }^{1} \mathrm{H}-\mathrm{NMR}$ spectrum we did not see the characteristic $\mathrm{OH}$ proton signal (17.41 ppm) (Figure S6a,b,c from Supplementary Materials). The aromatic signals were moved significantly to upfield (smaller $\delta$ ), which suggests the presence of pure nitrosophenol $5 \mathbf{b}^{\prime}$. Additionally, we observed hydrogen-deuterium (H/D) exchange between water- $d_{2} \mathrm{KOD}$ solution and aromatic protons. The experimental (UV-Vis and NMR studies for molecule $5 b$ ) and computational analysis (Figure S1 from Supplementary Materials) revealed that only in $\mathrm{KOH}$ and DMF solutions can we expect the presence of nitroso form $\mathbf{5} \mathbf{b}^{\prime}$. 
The nitroquinoline $\mathbf{4 b}$ with chlorine atom at C4 position was chosen in the next reaction, as the main difference complying with already used $4 \mathbf{a}$. In this case, two reactions were possible, i.e., direct nucleophilic displacement of aromatic hydrogen via VNS or $\mathrm{S}_{\mathrm{N}} \mathrm{Ar}$ of chloride located in activated $\mathrm{C} 4$ position. The molecule $4 \mathrm{~b}$ was treated with excess (1.5 equiv.) potassium $9 H$-carbazol-9-ide in THF solvent at reflux temperature, similarly to the previous experiment. The reaction was much more complex. The product with only a substituted chlorine atom at $\mathrm{C} 4$ position by $9 \mathrm{H}$-carbazole suggests a $\mathrm{S}_{\mathrm{N}} \mathrm{Ar}$ reaction. On the other hand, a product with only substituted aromatic hydrogen at C7 position by $9 \mathrm{H}$-carbazole suggests the occurrence of VNS reaction. Our results showed a complex reaction mixture. The product identified only by GC-MS suggests a structure of molecule $5 c$, which proves that both reactions proceed.

\subsection{Amination of Nitroquinoline Derivatives via Nitro Group Reduction with Stannous Chloride}

The obtained nitroquinolines 4 were easily reduced to appropriate aminoquinolines 6 in mild conditions. The synthetic route and structures of the aminoquinoline derivatives 6 are presented in Scheme 4. This method is suitable for various nitroquinolines 4 and tolerate to the presence of many useful functional groups, including hydroxyl, alkyl substituents, and halogen atoms. The reaction offers a simple and fast transformation, with yields of up to $86 \%$.<smiles>[R]c1ccnc2c([N+](=O)[O-])cccc12</smiles>

6a $57 \% ; \mathrm{R}^{1}=\mathrm{H}$ 6b $75 \% ; \mathbf{R}^{1}=\mathrm{Cl}$<smiles>[R]c1ccc(N[14C]C#CC(Cl)(Cl)Cl)c2nc(C)ccc12</smiles>

6c $51 \% ; R=B^{t}$ 6d $86 \% ; R=\mathrm{Pr}^{\mathrm{i}}$

Scheme 4. Synthesis routes of aminoquinoline derivatives 6 . Reagents and conditions: (i) $\mathrm{SnCl}_{2}, 6 \mathrm{M}$ $\mathrm{HCl}, \mathrm{MeOH}, \mathrm{T}>50^{\circ} \mathrm{C}$.

The ${ }^{1} \mathrm{H}-\mathrm{NMR}$ solution spectra of aminoquinolines 6 showed distinctive $\mathrm{H}-1$ signals from $\mathrm{NH}_{2}$ group proton with chemical shift ca. $4.9 \mathrm{ppm}\left(\mathrm{C} 8-\mathrm{NH}_{2}\right)$ or ca. $4.1 \mathrm{ppm}\left(\mathrm{C} 5-\mathrm{NH}_{2}\right)$. For all presented compounds 4, 5, and 6, distinctive H-1 and C-13 signals come from alkyl groups.

The analysis of the trends in ${ }^{1} \mathrm{H}$ and ${ }^{13} \mathrm{C}$ chemical shifts revealed that the aminoquinolines 6 molecules had significantly increased shielding effect (upfield effect, smaller $\delta$ ) in comparison with nitroquinolines 4 in $\mathrm{CDCl}_{3}$ solvent.

\subsection{X-ray Studies}

Crystals of compounds $4 \mathbf{b}, \mathbf{4 c}, \mathbf{5 a}$, and $5 \mathbf{b}$ were mounted in turn on a Gemini A Ultra Oxford Diffraction and SuperNova automatic diffractometer (Agilent Technologies, Santa Clara, CA, USA) equipped with a CCD detector used for data collection. X-ray intensity data were collected with graphite monochromated or with a micro-focused $\mathrm{MoK} \alpha$ radiation at room temperature, with $\omega$ scan mode. Details concerning crystal data 
and refinement are gathered in Table 1. Lorentz, polarization, and empirical absorption correction using spherical harmonics implemented in SCALE3 ABSPACK scaling algorithm were applied [14]. The structures were solved by a direct method and subsequently completed by a difference Fourier recycling. All the non-hydrogen atoms were refined anisotropically using full-matrix, least-squares techniques. The Olex2 [15], SHELXS and SHELXL [16] programs were used for all the calculations. Atomic scattering factors were incorporated in the computer programs. Details concerning crystal data and refinement are gathered in Table 2.

Table 2. Crystal data and structure refinement details of compounds $4 b, 4 c, 5 a$, and $5 b$.

\begin{tabular}{|c|c|c|c|c|}
\hline & $4 b$ & $4 c$ & $5 a$ & $5 b$ \\
\hline Empirical formula & $\mathrm{C}_{9} \mathrm{H}_{5} \mathrm{ClN}_{2} \mathrm{O}_{2}$ & $\mathrm{C}_{14} \mathrm{H}_{16} \mathrm{~N}_{2} \mathrm{O}_{2}$ & $\mathrm{C}_{21} \mathrm{H}_{13} \mathrm{~N}_{3} \mathrm{O}_{2}$ & $\mathrm{C}_{21} \mathrm{H}_{13} \mathrm{~N}_{3} \mathrm{O}_{2}$ \\
\hline Temperature (K) & 295(2) & 293(1) & 293(1) & 293(1) \\
\hline Wavelength $(\AA)$ & 0.71073 & 1.54184 & 1.54184 & 0.71073 \\
\hline Crystal system & orthorhombic & monoclinic & triclinic & orthorhombic \\
\hline Space group & $\mathrm{Pbc}_{1}$ & $P 2_{1} / \mathrm{c}$ & $P-1$ & $P$ na2 1 \\
\hline $\begin{array}{l}\text { Unit cell dimensions } \\
\qquad \begin{array}{c}\mathrm{a}(\AA) \\
\mathrm{b}(\AA) \\
\mathrm{c}(\AA) \\
\alpha\left(^{\circ}\right) \\
\beta\left(^{\circ}\right) \\
\gamma\left(\left(^{\circ}\right)\right.\end{array}\end{array}$ & $\begin{array}{c}7.4711(8) \\
15.429(2) \\
7.5911(11) \\
90 \\
90 \\
90\end{array}$ & $\begin{array}{c}13.4230(8) \\
6.9413(4) \\
28.5117(19) \\
90 \\
103.578(7) \\
90\end{array}$ & $\begin{array}{c}8.4004(4) \\
12.9693(7) \\
24.2324(16) \\
90.326(5) \\
91.364(4) \\
106.018(4)\end{array}$ & $\begin{array}{c}13.8510(6) \\
7.6712(4) \\
29.7991(14) \\
90 \\
90 \\
90\end{array}$ \\
\hline Volume $\left(\AA^{3}\right)$ & $875.0(2)$ & $2582.3(3)$ & $2536.6(2)$ & $3166.3(3)$ \\
\hline $\mathrm{Z}$ & 4 & 8 & 6 & 8 \\
\hline Calculated density $\left(\mathrm{g} / \mathrm{cm}^{3}\right)$ & 1.583 & 1.257 & 1.333 & 1.424 \\
\hline Absorption coefficient $\left(\mathrm{mm}^{-1}\right)$ & 0.406 & 0.689 & 0.715 & 0.094 \\
\hline $\mathrm{F}(000)$ & 424 & 1040 & 1056 & 1408 \\
\hline Crystal dimensions (mm) & $0.31 \times 0.27 \times 0.11$ & $0.31 \times 0.18 \times 0.09$ & $0.60 \times 0.05 \times 0.02$ & $0.54 \times 0.39 \times 0.07$ \\
\hline$\theta$ range for data collection $\left(^{\circ}\right)$ & 3.766 to 29.448 & 3.189 to 73.960 & 3.546 to 73.741 & 3.244 to 26.367 \\
\hline Index ranges & $\begin{array}{c}-10<\mathrm{h}<7 \\
-20<\mathrm{k}<21 \\
-7<1<10\end{array}$ & $\begin{array}{c}-11 \leq \mathrm{h} \leq 16 \\
-8 \leq \mathrm{k} \leq 8 \\
-34 \leq 1 \leq 29\end{array}$ & $\begin{array}{l}-10 \leq \mathrm{h} \leq 8 \\
-15 \leq \mathrm{k} \leq 15 \\
-29 \leq 1 \leq 29\end{array}$ & $\begin{aligned}-15 & \leq \mathrm{h} \leq 17 \\
-8 & \leq \mathrm{k} \leq 9 \\
-36 & \leq 1 \leq 37\end{aligned}$ \\
\hline Reflections collected & 3969 & 16911 & 18166 & 22268 \\
\hline Independent reflections & 1735 & 5152 & 9919 & 6198 \\
\hline Data / restraints / parameters & $1735 / 1 / 127$ & $5152 / 0 / 333$ & $9919 / 0 / 704$ & $6198 / 1 / 471$ \\
\hline Goodness-of-fit on $\mathrm{F}^{2}$ & 1.048 & 1.031 & 1.023 & 1.049 \\
\hline Final $\mathrm{R}$ indices $(\mathrm{I}>2 \sigma(\mathrm{I}))$ & $0.0394 / 0.0815$ & $0.0593 / 0.1731$ & $0.0733 / 0.2001$ & $0.0458 / 0.0848$ \\
\hline $\mathrm{R}$ indices (all data) & $0.0572 / 0.0907$ & $0.0808 / 0.2038$ & $0.1117 / 0.2538$ & $0.0675 / 0.0922$ \\
\hline Largest diff. Peak and hole & $-0.228 / 0.164$ & $0.223 /-0.178$ & $0.231 /-0.248$ & $0.117 /-0.163$ \\
\hline CCDC number & 1967406 & 2048040 & 2048038 & 2048039 \\
\hline
\end{tabular}

\section{Materials and Methods}

\subsection{Materials}

All experiments were carried out in an atmosphere of dry argon, and flasks were flame dried. Solvents were dried by usual methods (diphenyl ether, diethyl ether, and THF over benzophenone ketyl, $\mathrm{CHCl}_{3}$, and $\mathrm{CH}_{2} \mathrm{Cl}_{2}$ over $\mathrm{P}_{4} \mathrm{O}_{10}$, hexane over sodium-potassium alloy) and distilled. Chromatographic purification was carried out on silica gel $60(0.15-0.3$ 
mm, Macherey-Nagel GmbH \& Co. KG, Düren, Germany). Sodium hydride (dry, 95\%), potassium tert-butoxide, trimethyl orthoformate, 2-iso-propylaniline, 2-(tert-butyl)aniline, 2-nitroaniline, phosphoryl chloride, 9H-carbazole, Meldrum's acid, acrolein, and crotonaldehyde were purchased from Sigma-Aldrich (Poznań, Poland), and were used without further purification.

\subsection{Instrumentation}

NMR spectra were obtained with Avance 400 and 500 spectrometers (Bruker, Billerica, MA, USA) operating at 500.2 or $400.2 \mathrm{MHz}\left({ }^{1} \mathrm{H}\right)$ and 125.8 or $100.6 \mathrm{MHz}\left({ }^{13} \mathrm{C}\right)$ at $21^{\circ} \mathrm{C}$. Chemical shifts referenced to ext. TMS $\left({ }^{1} \mathrm{H},{ }^{13} \mathrm{C}\right)$ and ext. DSS $\left({ }^{1} \mathrm{H},{ }^{13} \mathrm{C}\right)$, or using the residual $\mathrm{CHCl}_{3}$ signal $\left(\delta_{\mathrm{H}} 7.26 \mathrm{ppm}\right)$ and $\mathrm{CDCl}_{3}\left(\delta_{\mathrm{C}} 77.1 \mathrm{ppm}\right)$ as internal references for ${ }^{1} \mathrm{H}$ and ${ }^{13} \mathrm{C}-\mathrm{NMR}$, respectively. Coupling constants are given in Hz. For GC-MS, a 7890A gas chromatograph (Agilent Technologies, Wilmington, DE, USA) was equipped with a MS (70 eV) 5975 EI/CI MSD, and a 7693 autosampler with an Agilent HP-5MS capillary column (30 $\mu \mathrm{m}$ $\times 250 \mu \mathrm{m} \times 0.25 \mu \mathrm{m}$ ) press. $127.5 \mathrm{kPa}$, total flow $19 \mathrm{~mL} / \mathrm{min}$, col. flow $2 \mathrm{~mL} / \mathrm{min}$, split-7:1, temp. prog. $\left(70{ }^{\circ} \mathrm{C}\right.$-hold $0.5 \mathrm{~min}, 70-290{ }^{\circ} \mathrm{C} / 25^{\circ} \mathrm{C} / \mathrm{min}$., $290{ }^{\circ} \mathrm{C}$-hold $6 \mathrm{~min}$ ) was used. The LCMS-IT-TOF analysis was performed on an Agilent 1200 Series binary LC system coupled to a micrOTOF-Q system mass spectrometer (Bruker Daltonics, Brema, Germany). High-resolution mass spectrometry (HRMS) measurements were performed using a Synapt G2-Si mass spectrometer (Waters, New Castle, DE, USA) equipped with an ESI source and quadrupole-time-of-flight mass analyser. To ensure accurate mass measurements, data were collected in centroid mode and mass was corrected during acquisition using leucine enkephalin solution as an external reference (Lock-SprayTM, Waters, New Castle, DE, USA). The measurement results were processed using the MassLynx 4.1 software (Waters, Milford, MA, USA) incorporated within the instrument. A Nicolet iS50 FTIR spectrometer was used for recording spectra in the IR range $4000-400 \mathrm{~cm}^{-1}$. FTIR spectra were recorded on a Perkin Elmer (Schwerzenbach, Switzerland) spectrophotometer in the spectral range $4000-450 \mathrm{~cm}^{-1}$ with the samples in the form of $\mathrm{KBr}$ pellets. Elementary analysis was performed using Vario EL III apparatus (Elementar, Langenselbold, Germany). Melting points were determined on MPA100 OptiMelt melting point apparatus (Stanford Research Systems, Sunnyvale, CA, USA) and are uncorrected.

3.3. Synthesis of 8-(tert-Butyl)-2-methylquinoline (3c), 8-(iso-Propyl)-2-methylquinoline (3d) and 8-Nitroquinoline (4a)

The synthesis of quinolines $\mathbf{3 c}, \mathbf{3 d}$, and $4 \mathbf{a}$ followed our procedure described in the literature [17].

Toluene $(50 \mathrm{~mL})$ and crotonaldehyde $(2.6 \mathrm{~mL}, 2.2 \mathrm{~g}, 31.4 \mathrm{mmol})$ were added to a solution of 2-(tert-butyl)aniline $(2.3 \mathrm{~g}, 15.7 \mathrm{mmol})$ in aqueous $6 \mathrm{M} \mathrm{HCl}(200 \mathrm{~mL})$ and were heated under reflux for $16 \mathrm{~h}$. The mixture was allowed to cool to room temperature. The aqueous layer was separated and neutralized with an aqueous solution of $\mathrm{K}_{2} \mathrm{CO}_{3}$. After extraction with $\mathrm{CH}_{2} \mathrm{Cl}_{2}(3 \times 50 \mathrm{~mL})$, the organic layer was separated and dried over $\mathrm{MgSO}_{4}$, and then was filtered and distilled bp $110-115^{\circ} \mathrm{C} / 3 \mathrm{mmHg}$. The liquid was purified by crystallization from hexane to afford white crystals:

8-(tert-Butyl)-2-methylquinoline (3c) [18] $2.4 \mathrm{~g}(12.2 \mathrm{mmol}, 78 \%) ; \mathrm{mp}=55.1-56.3{ }^{\circ} \mathrm{C}$; ${ }^{1} \mathrm{H}-\mathrm{NMR}\left(\mathrm{CDCl}_{3} ; 400.2 \mathrm{MHz}\right) \delta=1.68\left(\mathrm{~s}, 9 \mathrm{H}, \mathrm{C}\left(\mathrm{CH}_{3}\right)_{3}\right), 2.72\left(\mathrm{~s}, 3 \mathrm{H}, \mathrm{CH}_{3}\right), 7.21\left(\mathrm{~d}^{3}{ }^{3} \mathrm{~J}_{\mathrm{H}, \mathrm{H}}=\right.$ $8.4 \mathrm{~Hz}, 1 \mathrm{H}$, aromatic), $7.36\left(\mathrm{t}^{3}{ }^{3} \mathrm{H}_{\mathrm{H}, \mathrm{H}}=7.7 \mathrm{~Hz}, 1 \mathrm{H}\right.$, aromatic), $7.60(\mathrm{~m}, 2 \mathrm{H}$, aromatic), 7.98 $\left(\mathrm{d}^{3} \mathrm{~J}_{\mathrm{H}, \mathrm{H}}=8.4 \mathrm{~Hz}, 1 \mathrm{H}\right.$, aromatic $) ;{ }^{13} \mathrm{C}\left\{{ }^{1} \mathrm{H}\right\}-\mathrm{NMR}\left(\mathrm{CDCl}_{3} ; 100.6 \mathrm{MHz}\right) \delta=25.5,31.0,36.5$, 120.6, 125.0, 125.8, 126.3, 127.2, 136.4, 146.9, 147.5, 155.6.

Toluene $(50 \mathrm{~mL})$ and crotonaldehyde $(2.6 \mathrm{~mL}, 2.2 \mathrm{~g}, 31.4 \mathrm{mmol})$ were added to a solution of 2-iso-propylaniline (2.1 g, $15.7 \mathrm{mmol})$ in aqueous $6 \mathrm{M} \mathrm{HCl}(200 \mathrm{~mL})$ and were heated under reflux for $16 \mathrm{~h}$. The mixture was allowed to cool down to room temperature. The aqueous layer was separated and neutralized with aqueous solution of $\mathrm{K}_{2} \mathrm{CO}_{3}$. After extraction with $\mathrm{CH}_{2} \mathrm{Cl}_{2}(3 \times 50 \mathrm{~mL})$, the organic layer was separated and dried over $\mathrm{MgSO}_{4}$, and then was filtered and distilled bp $100-110^{\circ} \mathrm{C} / 3 \mathrm{mmHg}$. The liquid mixture was dissolved in concentrated $36 \% \mathrm{HCl}(100 \mathrm{~mL})$ at $5{ }^{\circ} \mathrm{C}$, and $\mathrm{ZnCl}_{2}(2.7 \mathrm{~g}, 20.0 \mathrm{mmol})$ 
was added with vigorous stirring for $1 \mathrm{~h}$. The precipitate was filtered, washed with cold 3 $\mathrm{M}$ aq. $\mathrm{HCl}$ and dried in air. The solid was washed with $i \mathrm{PrOH}$ and dried. The received white solid was added to $10 \%$ ammonia solution and extraction with $\mathrm{Et}_{2} \mathrm{O}(3 \times 50 \mathrm{~mL})$; the organic layer was separated and dried over $\mathrm{MgSO}_{4}$ to afford greenish oil:

8-(iso-Propyl)-2-methylquinoline (3d) [19] $2.1 \mathrm{~g}$ (11.6 mmol, 74\%); bp 100-110 ${ }^{\circ} \mathrm{C} / 3$ $\mathrm{mmHg} ;{ }^{1} \mathrm{H}-\mathrm{NMR}\left(\mathrm{CDCl}_{3} ; 400.2 \mathrm{MHz}\right) \delta=1.37\left(\mathrm{~d}^{3} \mathrm{~J}_{\mathrm{H}, \mathrm{H}}=7.0 \mathrm{~Hz}, 6 \mathrm{H}, \mathrm{CH}\left(\mathrm{CH}_{3}\right)_{2}\right), 2.73(\mathrm{~s}$, $\left.3 \mathrm{H}, \mathrm{CH}_{3}\right), 4.39$ (septet, $\left.{ }^{3} \mathrm{~J}_{\mathrm{H}, \mathrm{H}}=6.9 \mathrm{~Hz}, 1 \mathrm{H}, \mathrm{CH}\right), 7.23\left(\mathrm{~d}^{3} \mathrm{~J}_{\mathrm{H}, \mathrm{H}}=8.3 \mathrm{~Hz}, 1 \mathrm{H}\right.$, aromatic), 7.42 $\left(\mathrm{t}^{3} \mathrm{~J}_{\mathrm{H}, \mathrm{H}}=7.6 \mathrm{~Hz}, 1 \mathrm{H}\right.$, aromatic), $7.57\left(\mathrm{t},{ }^{3} \mathrm{~J}_{\mathrm{H}, \mathrm{H}}=7.1 \mathrm{~Hz}, 2 \mathrm{H}\right.$, aromatic $), 7.98\left(\mathrm{~d}^{3}{ }^{3} \mathrm{~J}_{\mathrm{H}, \mathrm{H}}=8.4\right.$ $\mathrm{Hz}, 1 \mathrm{H}$, aromatic); ${ }^{13} \mathrm{C}\left\{{ }^{1} \mathrm{H}\right\}-\mathrm{NMR}\left(\mathrm{CDCl}_{3} ; 125.8 \mathrm{MHz}\right) \delta=23.6,25.7,26.9,121.4,125.0,125.2$, $125.4,126.4,136.3,145.7,146.8,157.5$.

Toluene $(50 \mathrm{~mL})$ and acrolein $(2.1 \mathrm{~mL}, 1.8 \mathrm{~g}, 31.4 \mathrm{mmol})$ were added to a solution of 2-nitroaniline $(2.2 \mathrm{~g}, 15.7 \mathrm{mmol})$ in aqueous $6 \mathrm{M} \mathrm{HCl}(200 \mathrm{~mL})$ and were heated under reflux for $16 \mathrm{~h}$. The mixture was allowed to cool to room temperature. The aqueous layer was separated and neutralized with aqueous solution of $\mathrm{K}_{2} \mathrm{CO}_{3}$. After extraction with $\mathrm{CH}_{2} \mathrm{Cl}_{2}(3 \times 50 \mathrm{~mL})$, the organic layer was separated and dried over $\mathrm{MgSO}_{4}$, and then was filtered and evaporated to afford yellowish crystals:

8-Nitroquinoline (4a) [20] $2.6 \mathrm{~g}(14.8 \mathrm{mmol}, 94 \%) ; \mathrm{mp}=90.1-91.3^{\circ} \mathrm{C} ;{ }^{1} \mathrm{H}-\mathrm{NMR}\left(\mathrm{CDCl}_{3}\right.$; $400.2 \mathrm{MHz}) \delta=7.57\left(\mathrm{dd}^{3} J_{\mathrm{H}, \mathrm{H}}=8.4 \mathrm{~Hz},{ }^{3} J_{\mathrm{H}, \mathrm{H}}=4.2 \mathrm{~Hz}, 1 \mathrm{H}\right.$, aromatic), $7.63\left(\mathrm{t}^{3}{ }^{3} \mathrm{~J}_{\mathrm{H}, \mathrm{H}}=7.9 \mathrm{~Hz}\right.$, $1 \mathrm{H}$, aromatic), $8.05\left(2 \mathrm{~d},{ }^{3} J_{\mathrm{H}, \mathrm{H}}=7.9 \mathrm{~Hz}, 2 \mathrm{H}\right.$, aromatic), $8.28\left(\mathrm{~d}^{3} J_{\mathrm{H}, \mathrm{H}}=8.4 \mathrm{~Hz},{ }^{4} J_{\mathrm{H}, \mathrm{H}}=1.4 \mathrm{~Hz}\right.$, $1 \mathrm{H}$, aromatic), $9.08\left(\mathrm{dd},{ }^{3} \mathrm{~J}_{\mathrm{H}, \mathrm{H}}=4.1 \mathrm{~Hz},{ }^{3} \mathrm{~J}_{\mathrm{H}, \mathrm{H}}=1.4 \mathrm{~Hz}, 1 \mathrm{H}\right.$, aromatic); ${ }^{13} \mathrm{C}\left\{{ }^{1} \mathrm{H}\right\}-\mathrm{NMR}\left(\mathrm{CDCl}_{3}\right.$; $100.6 \mathrm{MHz}) \delta=122.8,123.8,125.3,129.1,132.1,136.2,139.6,147.5,152.7$.

\subsection{Synthesis of 4-Chloro-8-nitroquinoline (4b)}

\subsubsection{Step A}

Trimethyl orthoformate $(406.2 \mathrm{~g}, 500 \mathrm{~mL}, 3830.0 \mathrm{mmol})$ and Meldrum's acid (21.6 g, $150.0 \mathrm{mmol}$ ) were heated to a gentle reflux for $30 \mathrm{~min}$. The resulting greenish solution was cooled to $80^{\circ} \mathrm{C}$ and 2-nitroaniline $(15.0 \mathrm{~g}, 108.7 \mathrm{mmol}$ ) was added portion wise (exothermic reaction). The resulting mixture was stirred up to reflux for $2 \mathrm{~h}$, and left under room temperature (rt) for $16 \mathrm{~h}$. Subsequently, hexane was added and the solution was cooled to $-35{ }^{\circ} \mathrm{C}$ where a precipitate formed. The precipitate was filtered off, washed with diethyl ether $(4 \times 100 \mathrm{~mL})$, and dried to afford a white solid:

2,2-Dimethyl-5-(((2-nitrophenyl)amino)methylene)-1,3-dioxane-4,6-dione (2a) [21] $28.2 \mathrm{~g}$ (96.7 mmol, 89\%); mp $=175-178{ }^{\circ} \mathrm{C} ;{ }^{1} \mathrm{H}-\mathrm{NMR}\left(\mathrm{CDCl}_{3} ; 400.2 \mathrm{MHz}\right) \delta=1.77\left(\mathrm{~s}, 6 \mathrm{H}, 2 \mathrm{CH}_{3}\right)$, $7.41\left(\mathrm{~d},{ }^{3} J_{\mathrm{H}, \mathrm{H}}=7.8 \mathrm{~Hz}, 1 \mathrm{H}\right.$, aromatic), $7.66\left(\mathrm{~d},{ }^{3} \mathrm{~J}_{\mathrm{H}, \mathrm{H}}=8.3 \mathrm{~Hz}, 1 \mathrm{H}\right.$, aromatic), $7.79\left(\mathrm{t},{ }^{3} J_{\mathrm{H}, \mathrm{H}}=\right.$ $7.7 \mathrm{~Hz}, 1 \mathrm{H}$, aromatic), $8.32\left(\mathrm{~d},{ }^{3} J_{\mathrm{H}, \mathrm{H}}=7.6 \mathrm{~Hz}, 1 \mathrm{H}\right.$, aromatic $), 8.75\left(\mathrm{~d},{ }^{3} J_{\mathrm{H}, \mathrm{H}}=13.6 \mathrm{~Hz}, 1 \mathrm{H}\right.$, vinyl), $13.02\left(\mathrm{~d},{ }^{3} J_{\mathrm{H}, \mathrm{H}}=13.6 \mathrm{~Hz}, 1 \mathrm{H}, \mathrm{NH}\right) ;{ }^{13} \mathrm{C}\left\{{ }^{1} \mathrm{H}\right\}-\mathrm{NMR}\left(\mathrm{CDCl}_{3} ; 100.6 \mathrm{MHz}\right) \delta=27.3$, 91.4, 105.5, 118.0, 125.9, 127.0, 134.4, 136.1, 138.1, 151.2, 163.3, 164.2; UV-Vis (methanol; $\lambda(\mathrm{nm})$ $(\log \varepsilon)): 357$ (4.59), 308 (4.68), $274(4.49), 256$ (4.40), 216 (4.67); IR (KBr): $v=3161,3094,3004$, $1733,1686,1604,1518,1343,1265,1201,933,741 \mathrm{~cm}^{-1}$.

\subsubsection{Step B}

Into freshly distillated diphenyl ether $(50 \mathrm{~mL})$ at $220{ }^{\circ} \mathrm{C}$ was added $2 \mathrm{a}(2.92 \mathrm{~g}, 10.0$ $\mathrm{mmol}$ ) in small portions, resulting in vigorous gas evolution. The resulting orange solution was brought to reflux for $30 \mathrm{~min}$ and was then allowed to cool to $50^{\circ} \mathrm{C}$. The hexane $(25 \mathrm{~mL})$ was added and a brown solid precipitated was filtered and washed with hexane $(2 \times 10$ $\mathrm{mL}$ ). The crude product was purified by crystallization from chloroform/hexane mixture to yield solid as follows:

8-Nitro-4(1H)-quinolinone (3a) [21] $1.6 \mathrm{~g}(8.4 \mathrm{mmol}, 84 \%) ; \mathrm{mp}=192-194{ }^{\circ} \mathrm{C} ;{ }^{1} \mathrm{H}-\mathrm{NMR}$ (DMSO- $\left.d_{6} ; 500.2 \mathrm{MHz}\right) \delta=6.24\left(\mathrm{~d},{ }^{3} J_{\mathrm{H}, \mathrm{H}}=7.5 \mathrm{~Hz}, 1 \mathrm{H}\right.$, aromatic), $7.50\left(\mathrm{~d},{ }^{3} J_{\mathrm{H}, \mathrm{H}}=8.0 \mathrm{~Hz}\right.$, $1 \mathrm{H}$, aromatic), $7.97\left(\mathrm{~d},{ }^{3} J_{\mathrm{H}, \mathrm{H}}=7.5 \mathrm{~Hz}, 1 \mathrm{H}\right.$, aromatic), $8.56\left(\mathrm{~d},{ }^{3} J_{\mathrm{H}, \mathrm{H}}=7.9 \mathrm{~Hz}, 1 \mathrm{H}\right.$, aromatic), $8.63\left(\mathrm{~d},{ }^{3} \mathrm{~J}_{\mathrm{H}, \mathrm{H}}=7.9 \mathrm{~Hz}, 1 \mathrm{H}\right.$, aromatic), $11.86(\mathrm{~s}, 1 \mathrm{H}, \mathrm{NH}) ;{ }^{1} \mathrm{H}-\mathrm{NMR}\left(\mathrm{CDCl}_{3} ; 400.2 \mathrm{MHz}\right)$ $\delta=6.23\left(\mathrm{dd},{ }^{3} J_{\mathrm{H}, \mathrm{H}}=7.6 \mathrm{~Hz},{ }^{4} J_{\mathrm{H}, \mathrm{H}}=1.8 \mathrm{~Hz}, 1 \mathrm{H}\right.$, aromatic), $7.97\left(\mathrm{dd},{ }^{3} J_{\mathrm{H}, \mathrm{H}}=7.6 \mathrm{~Hz}, 1 \mathrm{H}\right.$, aromatic), $8.54-8.57(\mathrm{~m}, 1 \mathrm{H}$, aromatic), 8.58-8.64 $(\mathrm{m}, 1 \mathrm{H}$, aromatic), 11.86 (bs, $1 \mathrm{H}, \mathrm{NH})$; ${ }^{13} \mathrm{C}\left\{{ }^{1} \mathrm{H}\right\}-\mathrm{NMR}\left(\mathrm{CDCl}_{3} ; 100.6 \mathrm{MHz}\right) \delta=112.5,122.2,128.5,130.3,134.9,135.5,138.4,177.1$; 
${ }^{13} \mathrm{C}\left\{{ }^{1} \mathrm{H}\right\}-\mathrm{NMR}\left(\mathrm{DMSO}-d_{6} ; 125.8 \mathrm{MHz}\right) \delta=110.5,121.8,127.7,129.7,133.5,134.1,136.5,141.2$, 175.6; UV-Vis (methanol; $\lambda$ (nm) (loge)): 382 (4.07), 256 (4.30), 220 (4.51), 207 (4.54); IR (KBr): $v=3331,3234,1643,1605,1564,1490,1314,1291,1245,1188,1068,745 \mathrm{~cm}^{-1}$.

\subsubsection{Step C}

Into freshly distillated phosphoryl chloride $(82.0 \mathrm{~g}, 50 \mathrm{~mL}, 534.8 \mathrm{mmol})$ under argon, 3a $(0.9 \mathrm{~g}, 5.0 \mathrm{mmol})$ was mixed, and the resulting solution was stirred at $90{ }^{\circ} \mathrm{C}$ for 4 $\mathrm{h}$. The excess of phosphoryl chloride was slowly evaporated under reduced pressure. The reaction mixture was slowly added to a well-stirred mixture of ice $(50 \mathrm{~g})$ in water (100 $\mathrm{mL}$ ). After stirring for $15 \mathrm{~min}$, the resulting reaction mixture was carefully brought to $\mathrm{pH}$ $13-14$ by adding $\mathrm{NaOH}$ solution (40\%). The aqueous layer was extracted with $\mathrm{CH}_{2} \mathrm{Cl}_{2}(4 \times$ $10 \mathrm{~mL}$ ). The combined organic layers were separated and dried over $\mathrm{MgSO}_{4}$. Evaporation of the brown-colored solvent afforded $4 \mathrm{~b}$ as light tan crystals. Next, the crude products were purified by chromatography on silica gel using methanol/dichloromethane as eluent and finally crystallization from $\mathrm{CH}_{2} \mathrm{Cl}_{2}$ to yield precipitates as follows:

4-Chloro-8-nitroquinoline (4b) [22] $0.8 \mathrm{~g}(4.0 \mathrm{mmol}, 81 \%) ; \mathrm{mp}=120-125{ }^{\circ} \mathrm{C} ;{ }^{1} \mathrm{H}-\mathrm{NMR}$ (DMSO- $\left.d_{6} ; 400.2 \mathrm{MHz}\right) \delta=7.93\left(\mathrm{dd},{ }^{3} J_{\mathrm{H}, \mathrm{H}}=8.1 \mathrm{~Hz},{ }^{3} J_{\mathrm{H}, \mathrm{H}}=7.9 \mathrm{~Hz}, 1 \mathrm{H}\right.$, aromatic), $7.98(\mathrm{~d}$, ${ }^{3} J_{\mathrm{H}, \mathrm{H}}=4.7 \mathrm{~Hz}, 1 \mathrm{H}$, aromatic), $8.39\left(\mathrm{dd},{ }^{3} J_{\mathrm{H}, \mathrm{H}}=7.5 \mathrm{~Hz},{ }^{4} J_{\mathrm{H}, \mathrm{H}}=0.8 \mathrm{~Hz}, 1 \mathrm{H}\right.$, aromatic), 8.48 $\left(\mathrm{dd},{ }^{3} J_{\mathrm{H}, \mathrm{H}}=8.5 \mathrm{~Hz},{ }^{4} J_{\mathrm{H}, \mathrm{H}}=0.9 \mathrm{~Hz}, 1 \mathrm{H}\right.$, aromatic), $8.98\left(\mathrm{~d},{ }^{3} J_{\mathrm{H}, \mathrm{H}}=4.7 \mathrm{~Hz}, 1 \mathrm{H}\right.$, aromatic); ${ }^{13} \mathrm{C}\left\{{ }^{1} \mathrm{H}\right\}$-NMR (DMSO- $\left.d_{6} ; 100.6 \mathrm{MHz}\right) \delta=123.4,124.1,126.3,127.40,127.42,139.3,141.9$, 148.2, 152.5; GC-MS: $\mathrm{t}_{\mathrm{r}}=7.228 \mathrm{~min},(\mathrm{EI}) \mathrm{M}^{+}=208(100 \%),\left(\mathrm{M}-\mathrm{NO}_{2}\right)^{+}=162(33 \%)$; GC-MS: $\mathrm{t}_{\mathrm{r}}=7.3 \mathrm{~min},(\mathrm{EI}) \mathrm{M}^{+}=208.1(100 \%) ; \mathrm{UV}-\mathrm{Vis}(\mathrm{methanol} ; \lambda(\mathrm{nm})(\log \varepsilon)): 316$ (4.23), $302(4.30)$, 283 (4.47), 216 (5.02); IR (KBr): $v=3047,1958,1847,1535,1484,1358,880,865,750,717$ $\mathrm{cm}^{-1}$; CCDC (The Cambridge Crystallographic Data Centre) 1967406.

\subsection{Synthesis of 8-(Alkyl)-2-methyl-5-nitroquinolines $4 \mathbf{c}$ and $4 \mathbf{d}$}

8-(Alkyl)-2-methylquinoline $3 \mathbf{c}$ or $3 \mathbf{d}(7.5 \mathrm{mmol})$ was dissolved in a mixture of concentrated $\mathrm{H}_{2} \mathrm{SO}_{4}$ and $\mathrm{HNO}_{3}$ (4.5 and $10.5 \mathrm{~mL}$, respectively) at $5{ }^{\circ} \mathrm{C}$. After stirring for $1 \mathrm{~h}$ at room temperature, no evolution of gas was observed, so the reaction mixture was heated up to $70{ }^{\circ} \mathrm{C}$ and stirred overnight. After this time, the reaction mixture was poured down to a beaker containing $25 \mathrm{~g}$ of ice and $25 \mathrm{~mL}$ of water and the precipitated solid was filtered off, washed with $10 \mathrm{~mL}$ of cold water, and dried on air, giving:

8-(tert-Butyl)-2-methyl-5-nitroquinoline (4c) as a yellow solid. $1.1 \mathrm{~g}(4.6 \mathrm{mmol}, 61 \%) ; \mathrm{mp}$ $=86.1-87.3^{\circ} \mathrm{C} ;{ }^{1} \mathrm{H}-\mathrm{NMR}\left(\mathrm{CDCl}_{3} ; 500.2 \mathrm{MHz}\right) \delta=1.69\left(\mathrm{~s}, 9 \mathrm{H}, \mathrm{C}\left(\mathrm{CH}_{3}\right)_{3}\right), 2.77\left(\mathrm{~s}, 3 \mathrm{H}, \mathrm{CH}_{3}\right)$, $7.45\left(\mathrm{~d}_{,}^{3} J_{\mathrm{H}, \mathrm{H}}=8.9 \mathrm{~Hz}, 1 \mathrm{H}\right.$, aromatic), $7.70\left(\mathrm{~d}^{3} \mathrm{~J}_{\mathrm{H}, \mathrm{H}}=8.3 \mathrm{~Hz}, 1 \mathrm{H}\right.$, aromatic $), 8.17\left(\mathrm{~d}^{3}{ }^{3} \mathrm{~J}_{\mathrm{H}, \mathrm{H}}=\right.$ $8.3 \mathrm{~Hz}, 1 \mathrm{H}$, aromatic), $8.85\left(\mathrm{~d}^{3} \mathrm{~J}_{\mathrm{H}, \mathrm{H}}=8.9 \mathrm{~Hz}, 1 \mathrm{H}\right.$, aromatic $) ;{ }^{13} \mathrm{C}\left\{{ }^{1} \mathrm{H}\right\}-\mathrm{NMR}\left(\mathrm{CDCl}_{3} ; 125.8\right.$ MHz) $\delta=25.4,31.1,37.7,119.9,123.2,123.6,124.4,132.0,144.6,146.8,155.9,157.2$; UV-Vis (methanol; $\lambda(\mathrm{nm})(\log \varepsilon)): 317$ (4.02), 281 (3.94), 258 (4.00), 224 (4.66), 202 (4.61); IR (KBr): $v=2959,1909,1609,1517,1500,1333,827,801 \mathrm{~cm}^{-1}$; Anal. Calcd for $\mathrm{C}_{14} \mathrm{H}_{16} \mathrm{~N}_{2} \mathrm{O}_{2}$ : C, 68.83; H, 6.60; N, 11.47; O, 13.10 Found: C, 69.00; H, 6.66; N, 11.33; CCDC (The Cambridge Crystallographic Data Centre) 2048040.

8-(iso-Propyl)-2-methyl-5-nitroquinoline (4d) as a beige solid. $1.3 \mathrm{~g}(5.7 \mathrm{mmol}, 76 \%)$; $\mathrm{mp}$ $=59.1-60.3{ }^{\circ} \mathrm{C} ;{ }^{1} \mathrm{H}-\mathrm{NMR}\left(\mathrm{CDCl}_{3} ; 500.2 \mathrm{MHz}\right) \delta=1.38\left(\mathrm{~d}^{3} \mathrm{~J}_{\mathrm{H}, \mathrm{H}}=6.9 \mathrm{~Hz}, 6 \mathrm{H}, \mathrm{CH}\left(\mathrm{CH}_{3}\right)_{2}\right)$, $2.79\left(\mathrm{~s}, 3 \mathrm{H}, \mathrm{CH}_{3}\right), 4.47\left(\right.$ septet, $\left.^{3} \mathrm{~J}_{\mathrm{H}, \mathrm{H}}=6.9 \mathrm{~Hz}, 1 \mathrm{H}, \mathrm{CH}\right), 7.50\left(\mathrm{~d}^{3}{ }^{3} \mathrm{~J}_{\mathrm{H}, \mathrm{H}}=8.9 \mathrm{~Hz}, 1 \mathrm{H}\right.$, aromatic), $7.64\left(\mathrm{~d}^{3} \mathrm{~J}_{\mathrm{H}, \mathrm{H}}=8.1 \mathrm{~Hz}, 1 \mathrm{H}\right.$, aromatic), $8.28\left(\mathrm{~d}^{3} \mathrm{~J}_{\mathrm{H}, \mathrm{H}}=8.1 \mathrm{~Hz}, 1 \mathrm{H}\right.$, aromatic), $8.92\left(\mathrm{~d}^{3}{ }^{3} \mathrm{~J}_{\mathrm{H}, \mathrm{H}}=\right.$ $8.9 \mathrm{~Hz}, 1 \mathrm{H}$, aromatic); ${ }^{13} \mathrm{C}\left\{{ }^{1} \mathrm{H}\right\}-\mathrm{NMR}\left(\mathrm{CDCl}_{3} ; 125.8 \mathrm{MHz}\right) \delta=23.3,25.4,27.9,119.4,123.5$, $123.8,124.4,132.2,143.5,145.3,155.3,159.0$; UV-Vis (methanol; $\lambda(\mathrm{nm})(\log \varepsilon)): 321(4.06)$, 225 (4.67), 202 (4.55); IR (KBr): $v=2963,1960,1895,1606,1517,1449,1342,803 \mathrm{~cm}^{-1}$; Anal. Calcd for $\mathrm{C}_{13} \mathrm{H}_{14} \mathrm{~N}_{2} \mathrm{O}_{2}$ : C, 67.81; H, 6.13; N, 12.17; O, 13.90 Found: $\mathrm{C}, 67.94 ; \mathrm{H}, 6.19 ; \mathrm{N}$, 12.01 .

\subsection{Syntheses of 9H-Carbazol-9-yl-8-nitroquinolines $\mathbf{5 a}$ and $\mathbf{5 b}$}

These were based on the procedure described in the literature [8]. To the suspension of tert-BuOK $(1.01 \mathrm{~g}, 9.04 \mathrm{mmol})$ in THF $(50 \mathrm{~mL}), 9 H$-carbazole $(1.1 \mathrm{~g}, 6.58 \mathrm{mmol})$ was 
added and reagents were stirred under reflux for $30 \mathrm{~min}$ under argon. 8-Nitroquinoline $4 \mathbf{a}, \mathbf{4 b}$, or $4 \mathbf{d}(4.52 \mathrm{mmol})$, respectively was then added to the reaction mixture, which was refluxed overnight. After the evaporation of the solvent to give a solid, water $(20 \mathrm{~mL})$ and $\mathrm{CH}_{2} \mathrm{Cl}_{2}(100 \mathrm{~mL})$ were added. The organic layer was separated and the aqueous layer was extracted with $\mathrm{CH}_{2} \mathrm{Cl}_{2}(4 \times 50 \mathrm{~mL})$. The combined organic layers were dried over $\mathrm{MgSO}_{4}$. After solvent evaporating, the crude product was purified by column chromatography on silica gel using methanol/dichloromethane as eluent to afford a crude solid, and finally crystallization from a mixture of $\mathrm{CH}_{2} \mathrm{Cl}_{2}$ and hexane to yield solids as follows:

9-(8-Nitroquinolin-7-yl)-9H-carbazole (5a) $0.11 \mathrm{~g}(0.3 \mathrm{mmol}, 7 \%) ; \mathrm{mp}=160-163{ }^{\circ} \mathrm{C} ;{ }^{1} \mathrm{H}-$ $\mathrm{NMR}\left(\mathrm{CDCl}_{3}, 500.2 \mathrm{MHz}\right) \delta=7.20\left(\mathrm{dt}^{3}{ }^{3} J_{\mathrm{H}, \mathrm{H}}=8.1 \mathrm{~Hz},{ }^{4} J_{\mathrm{H}, \mathrm{H}}=0.9 \mathrm{~Hz}, 2 \mathrm{H}\right.$, aromatic $), 7.32$ $\left(\mathrm{ddd},{ }^{3} J_{\mathrm{H}, \mathrm{H}}=8.1 \mathrm{~Hz},{ }^{4} J_{\mathrm{H}, \mathrm{H}}=7.2 \mathrm{~Hz},{ }^{4} J_{\mathrm{H}, \mathrm{H}}=1.0 \mathrm{~Hz}, 2 \mathrm{H}\right.$, aromatic), 7.40 (ddd, ${ }^{3} J_{\mathrm{H}, \mathrm{H}}=8.3 \mathrm{~Hz}$, ${ }^{4} J_{\mathrm{H}, \mathrm{H}}=7.2 \mathrm{~Hz},{ }^{4} J_{\mathrm{H}, \mathrm{H}}=1.3 \mathrm{~Hz}, 2 \mathrm{H}$, aromatic), $7.60\left(\mathrm{~d},{ }^{3} J_{\mathrm{H}, \mathrm{H}}=8.7 \mathrm{~Hz}, 1 \mathrm{H}\right.$, aromatic), 7.69 $\left(\mathrm{dd},{ }^{3} J_{\mathrm{H}, \mathrm{H}}=8.4 \mathrm{~Hz},{ }^{4} J_{\mathrm{H}, \mathrm{H}}=4.3 \mathrm{~Hz}, 1 \mathrm{H}\right.$, aromatic), $8.12\left(\mathrm{ddd},{ }^{3} J_{\mathrm{H}, \mathrm{H}}=7.8 \mathrm{~Hz},{ }^{4} J_{\mathrm{H}, \mathrm{H}}=1.3 \mathrm{~Hz}\right.$, ${ }^{4} J_{\mathrm{H}, \mathrm{H}}=0.8 \mathrm{~Hz}, 2 \mathrm{H}$, aromatic), $8.16\left(\mathrm{~d},{ }^{3} J_{\mathrm{H}, \mathrm{H}}=8.7 \mathrm{~Hz}, 1 \mathrm{H}\right.$, aromatic $), 8.39\left(\mathrm{dd},{ }^{3} J_{\mathrm{H}, \mathrm{H}}=8.4\right.$ $\mathrm{Hz},{ }^{4} J_{\mathrm{H}, \mathrm{H}}=1.7 \mathrm{~Hz}, 1 \mathrm{H}$, aromatic), $9.14\left(\mathrm{dd},{ }^{3} J_{\mathrm{H}, \mathrm{H}}=4.3 \mathrm{~Hz},{ }^{4} J_{\mathrm{H}, \mathrm{H}}=1.7 \mathrm{~Hz}, 1 \mathrm{H}\right.$, aromatic); ${ }^{13} \mathrm{C}\left\{{ }^{1} \mathrm{H}\right\}-\mathrm{NMR}\left(\mathrm{CDCl}_{3} ; 125.8 \mathrm{MHz}\right) \delta=110.2,120.6,121.2,123.6,124.3,126.6,127.8,128.8$, $130.5,131.3,136.1,140.5,141.5,148.0,153.3$; HRMS (IT-TOF): $m / z$ Calcd for $\mathrm{C}_{21} \mathrm{H}_{14} \mathrm{~N}_{3} \mathrm{O}_{2}$ $(\mathrm{M}+\mathrm{H})^{+}=340.1086$, Found 340.1094; UV-Vis (methanol; $\lambda(\mathrm{nm})(\log \varepsilon)$ ): 329 (3.74), 315 (3.74), 287 (4.21), 225 (4.88), 206 (4.69); IR (KBr): $v=3060,2925,1731,1541,1450,1225,757$ $\mathrm{cm}^{-1}$; CCDC (The Cambridge Crystallographic Data Centre) 2048038.

(Z)-7-(9H-Carbazol-9-yl)-8-(hydroxyimino)quinolin-5(8H)-one (5b) $0.24 \mathrm{~g}$ (0.7 mmol, 16\%); $\mathrm{mp}_{\text {dec. }}=210-211{ }^{\circ} \mathrm{C} ;{ }^{1} \mathrm{H}-\mathrm{NMR}\left(\mathrm{CDCl}_{3}, 500.2 \mathrm{MHz}\right) \delta=6.97(\mathrm{~s}, 1 \mathrm{H}$, aromatic), 7.31 (ddd, ${ }^{3} J_{\mathrm{H}, \mathrm{H}}=8.0 \mathrm{~Hz},{ }^{4} J_{\mathrm{H}, \mathrm{H}}=4.7 \mathrm{~Hz},{ }^{4} J_{\mathrm{H}, \mathrm{H}}=3.4 \mathrm{~Hz}, 2 \mathrm{H}$, aromatic), $7.42\left(\mathrm{dd},{ }^{3} J_{\mathrm{H}, \mathrm{H}}=3.6 \mathrm{~Hz},{ }^{4} J_{\mathrm{H}, \mathrm{H}}\right.$ $=1.0 \mathrm{~Hz}, 4 \mathrm{H}$, aromatic), $7.84\left(\mathrm{dd},{ }^{3} J_{\mathrm{H}, \mathrm{H}}=8.0,{ }^{4} J_{\mathrm{H}, \mathrm{H}}=4.9,1 \mathrm{H}\right.$, aromatic $), 8.10\left(\mathrm{dt},{ }^{3} J_{\mathrm{H}, \mathrm{H}}=7.8\right.$, ${ }^{4} J_{\mathrm{H}, \mathrm{H}}=1.0,2 \mathrm{H}$, aromatic), $8.81\left(\mathrm{dd},{ }^{3} J_{\mathrm{H}, \mathrm{H}}=8.0,{ }^{4} J_{\mathrm{H}, \mathrm{H}}=1.8 \mathrm{~Hz}, 1 \mathrm{H}\right.$, aromatic), $8.88\left(\mathrm{dd},{ }^{3} J_{\mathrm{H}, \mathrm{H}}\right.$ $=4.9 \mathrm{~Hz},{ }^{4} J_{\mathrm{H}, \mathrm{H}}=1.8 \mathrm{~Hz}, 1 \mathrm{H}$, aromatic $), 17.76(\mathrm{~s}, 1 \mathrm{H}, \mathrm{OH}) ;{ }^{1} \mathrm{H}-\mathrm{NMR}\left(\mathrm{DMSO}-d_{6}, 500.2 \mathrm{MHz}\right)$ $\delta=7.03\left(\mathrm{~s}, 1 \mathrm{H}\right.$, aromatic), $7.29\left(\mathrm{dd},{ }^{3} \mathrm{~J}_{\mathrm{H}, \mathrm{H}}=7.4 \mathrm{~Hz}, 2 \mathrm{H}\right.$, aromatic), $7.43\left(\mathrm{dd},{ }^{3} J_{\mathrm{H}, \mathrm{H}}=7.3 \mathrm{~Hz}\right.$, $2 \mathrm{H}$, aromatic), $7.56\left(\mathrm{~d},{ }^{3} J_{\mathrm{H}, \mathrm{H}}=8.2 \mathrm{~Hz}, 2 \mathrm{H}\right.$, aromatic), $8.03\left(\mathrm{dd},{ }^{3} J_{\mathrm{H}, \mathrm{H}}=8.0 \mathrm{~Hz},{ }^{4} J_{\mathrm{H}, \mathrm{H}}=4.9\right.$ $\mathrm{Hz}, 1 \mathrm{H}$, aromatic), $8.21\left(\mathrm{~d},{ }^{3} J_{\mathrm{H}, \mathrm{H}}=7.7 \mathrm{~Hz}, 2 \mathrm{H}\right.$, aromatic $), 8.74\left(\mathrm{dd},{ }^{3} J_{\mathrm{H}, \mathrm{H}}=8.0 \mathrm{~Hz},{ }^{4} J_{\mathrm{H}, \mathrm{H}}=\right.$ $1.5 \mathrm{~Hz}, 1 \mathrm{H}$, aromatic), $9.07\left(\mathrm{dd},{ }^{3} J_{\mathrm{H}, \mathrm{H}}=4.9 \mathrm{~Hz},{ }^{4} J_{\mathrm{H}, \mathrm{H}}=1.5 \mathrm{~Hz}, 1 \mathrm{H}\right.$, aromatic), $17.41(\mathrm{~s}, 1 \mathrm{H}$, $\mathrm{OH}) ;{ }^{1} \mathrm{HNMR}\left(\mathrm{DMSO}-d_{6} / \mathrm{KOD}, 500.2 \mathrm{MHz}\right) \delta=7.19-7.33\left(\mathrm{~m},{ }^{3} J_{\mathrm{H}, \mathrm{H}}=7.0 \mathrm{~Hz},{ }^{4} J_{\mathrm{H}, \mathrm{H}}=0.8\right.$ $\mathrm{Hz}, 4 \mathrm{H}$, aromatic), $7.40\left(\mathrm{t},{ }^{3} J_{\mathrm{H}, \mathrm{H}}=7.4 \mathrm{~Hz}, 2 \mathrm{H}\right.$, aromatic), $7.55\left(\mathrm{dd},{ }^{3} J_{\mathrm{H}, \mathrm{H}}=7.9 \mathrm{~Hz},{ }^{4} J_{\mathrm{H}, \mathrm{H}}=\right.$ $4.4 \mathrm{~Hz}, 1 \mathrm{H}$, aromatic), $8.23\left(\mathrm{~d},{ }^{3} J_{\mathrm{H}, \mathrm{H}}=7.6 \mathrm{~Hz}, 2 \mathrm{H}\right.$, aromatic), $8.66\left(\mathrm{dd},{ }^{3} J_{\mathrm{H}, \mathrm{H}}=8.1 \mathrm{~Hz},{ }^{4} J_{\mathrm{H}, \mathrm{H}}=\right.$ $2.0 \mathrm{~Hz}, 1 \mathrm{H}$, aromatic), 8.94 (bs, $1 \mathrm{H}$, aromatic); ${ }^{13} \mathrm{C}\left\{{ }^{1} \mathrm{H}\right\}-\mathrm{NMR}\left(\mathrm{CDCl}_{3} ; 125.8 \mathrm{MHz}\right) \delta=111.2$, $120.5,121.2,124.6,126.0,126.3,126.4,126.7,136.7,140.2,141.3,147.6,148.1,150.2,182.4$; MS (IT-TOF): $m / z$ (relative intensity (rel. int.) $(\mathrm{M}+\mathrm{H})^{+}=340.1091(100 \%) ;\left(\mathrm{M}-\mathrm{H}_{2} \mathrm{O}\right)^{+}=$ $322.0984(23 \%) ;(\mathrm{M}+\mathrm{Na})^{+}=362.0913(9 \%) ; \mathrm{HRMS}$ (IT-TOF): $m / z$ Calcd for $\mathrm{C}_{21} \mathrm{H}_{14} \mathrm{~N}_{3} \mathrm{O}_{2}(\mathrm{M}$ $+\mathrm{H})^{+}=340.1086$, Found 340.1091; UV-Vis $(1 \mathrm{M} \mathrm{KOH} ; \lambda(\mathrm{nm})(\log \varepsilon)): 406(4.22), 330(3.83)$, 318 (3.86), 287 (4.10), 276 (4.13), 234 (4.63); (DMF; $\lambda$ (nm) (loge)): 430 (3.56), 330 (4.13), 317 (4.18); (DMSO; $\lambda(\mathrm{nm})(\log \varepsilon)): 430$ (3.00), 331 (3.77), 320 (3.81), 290 (4.03); (ACN; $\lambda(\mathrm{nm})$ (log $\varepsilon)$ ): 444 (2.64), 330 (3.63), 317 (3.71), 289 (3.78), 228 (4.10); (methanol; $\lambda(\mathrm{nm})(\log \varepsilon)): 453$ (3.22), 328 (4.13), 317 (4.17), 287 (4.37), 228 (4.69); (THF; $\lambda$ (nm) (loge)): 459(3.18), 330 (4.11), 318 (4.15), 288 (4.34), 239 (4.55); $\left(\mathrm{CDCl}_{3} ; \lambda\right.$ (nm) (log $\left.\varepsilon\right)$ ): 478(3.35), 329 (4.23), 318 (4.24), 289 (4.42); IR (KBr): $v=3045,2927,1649,1601,1447,1298,750,719 \mathrm{~cm}^{-1}$; CCDC 2048039.

9-(8-isoPropyl-2-((8-isopropyl-2-methyl-5-nitroquinolin-6-yl)methyl)-5-nitrosoquinolin-6-yl)9H-carbazole (5d) $0.61 \mathrm{~g}(1.0 \mathrm{mmol}, 44 \%) ; \mathrm{mp}=290.1-291.3{ }^{\circ} \mathrm{C} ;{ }^{1} \mathrm{H}-\mathrm{NMR}\left(\mathrm{CDCl}_{3}, 500.2\right.$ $\mathrm{MHz}) \delta=1.48\left(\mathrm{~d},{ }^{3} \mathrm{~J}_{\mathrm{H}, \mathrm{H}}=6.8 \mathrm{~Hz}, 6 \mathrm{H}, \mathrm{CH}\left(\mathrm{CH}_{3}\right)_{2}\right), 1.56\left(\mathrm{~d},{ }^{3} \mathrm{~J}_{\mathrm{H}, \mathrm{H}}=7.0 \mathrm{~Hz}, 6 \mathrm{H}, \mathrm{CH}\left(\mathrm{CH}_{3}\right)_{2}\right)$, $2.80\left(\mathrm{~s}, 3 \mathrm{H}, \mathrm{CH}_{3}\right), 4.24$ (septet, $\left.{ }^{3} J_{\mathrm{H}, \mathrm{H}}=6.8 \mathrm{~Hz}, 1 \mathrm{H}, \mathrm{CH}\right), 4.47$ (septet, ${ }^{3} J_{\mathrm{H}, \mathrm{H}}=6.8 \mathrm{~Hz}, 1 \mathrm{H}$, $\mathrm{CH}), 7.26\left(\mathrm{~s}, 2 \mathrm{H}\right.$, aromatic), $7.36\left(\mathrm{dt}^{3} \mathrm{~J}_{\mathrm{H}, \mathrm{H}}=7.1 \mathrm{~Hz},{ }^{4} J_{\mathrm{H}, \mathrm{H}}=0.7 \mathrm{~Hz}, 2 \mathrm{H}\right.$, aromatic $), 7.41-7.47$ (m, 3H, aromatic), $7.80\left(\mathrm{~s}, 1 \mathrm{H}\right.$, aromatic), $8.17\left(\mathrm{~d},{ }^{3} J_{\mathrm{H}, \mathrm{H}}=7.8 \mathrm{~Hz}, 2 \mathrm{H}\right.$, aromatic), 8.50 (s, $2 \mathrm{H}$, aromatic), $8.54\left(\mathrm{~s}, 1 \mathrm{H}\right.$, aromatic), $8.77\left(\mathrm{~d},{ }^{3} \mathrm{~J}_{\mathrm{H}, \mathrm{H}}=8.1 \mathrm{~Hz}, 1 \mathrm{H}\right.$, aromatic); ${ }^{13} \mathrm{C}\left\{{ }^{1} \mathrm{H}\right\}-\mathrm{NMR}$ $\left(\mathrm{CDCl}_{3} ; 125.8 \mathrm{MHz}\right) \delta=23.1,23.3,25.6,27.9,28.6,109.6,115.3,115.6,116.6,120.6,120.7$, $121.1,121.3,122.2,124.1,126.5,126.6,129.4,132.1,132.4,140.9,143.6,144.9,148.49,148.54$, $149.4,154.1,156.4,160.2,160.6$; MS (ES-TOF): $m / z$ (rel. int.) $\mathrm{M}^{+}=606.2502$ (100\%), (9-(8- 
isopropyl-2-methyl-5-nitrosoquinolin-6-yl)-9H-carbazole "VNS product" Scheme 3) Calcd for $\mathrm{C}_{25} \mathrm{H}_{21} \mathrm{~N}_{3} \mathrm{O}(\mathrm{M}-2 \mathrm{H})^{+}=377.2294(20 \%)$; HRMS (AP-TOF): $\mathrm{m} / z$ Calcd. for $\mathrm{C}_{38} \mathrm{H}_{32} \mathrm{~N}_{5} \mathrm{O}_{3}$ $\mathrm{M}^{+}=606.2505$, Found 606.2505; UV-Vis (methanol; $\left.\lambda(\mathrm{nm})(\log \varepsilon)\right): 381$ (4.46), 327 (4.17), 287 (4.57), 230 (4.86); IR (KBr): $v=2962,1600,1529,1452,1316,1228,750 \mathrm{~cm}^{-1}$.

\subsection{Syntheses of Aminoquinolines $\mathbf{6}$}

Stannous chloride crystal $(47.4 \mathrm{~g}, 250.0 \mathrm{mmol})$ was added to a stirred solution of nitroquinoline $4 \mathbf{a}, 4 \mathbf{b}, 4 \mathbf{c}$, or $4 \mathrm{~d}(25.0 \mathrm{mmol})$, respectively, and $6 \mathrm{M}$ hydrochloric acid (100 $\mathrm{mL}$ ) in methanol ( $300 \mathrm{~mL}$ ). After being stirred for $0.5 \mathrm{~h}$ at $\mathrm{rt}$, the reaction mixture was heated to $40-50{ }^{\circ} \mathrm{C}$ for $2 \mathrm{~h}$ (only for $\mathbf{4 b}$ ) or was brought to reflux and stirred for $3 \mathrm{~h}$. After cooling to $\mathrm{rt}$, the mixture was basified with aqueous ammonia and extracted with chloroform $(3 \times$ $50 \mathrm{~mL}$ ). The combined extract was dried over $\mathrm{MgSO}_{4}$ and evaporated to afford a solid (or liquid for 6e), which was purified by crystallization from chloroform/hexane mixture to yield precipitates as follows (or was distilled bp $110-115^{\circ} \mathrm{C} / 3 \mathrm{mmHg}$ for $6 \mathbf{e}$ to afford red oil):

Quinolin-8-amine (6a) [23] as a beige solid $2.0 \mathrm{~g}(13.9 \mathrm{mmol}, 57 \%) ; \mathrm{mp}=62-63{ }^{\circ} \mathrm{C}$; ${ }^{1} \mathrm{H}-\mathrm{NMR}\left(\mathrm{CDCl}_{3} ; 400.2 \mathrm{MHz}\right) \delta=4.98\left(\mathrm{bs}, 2 \mathrm{H}, \mathrm{NH}_{2}\right), 6.93\left(\mathrm{~d},{ }^{3} J_{\mathrm{H}, \mathrm{H}}=7.5 \mathrm{~Hz}, 1 \mathrm{H}\right.$, aromatic), $7.15\left(\mathrm{~d},{ }^{3} J_{\mathrm{H}, \mathrm{H}}=8.1 \mathrm{~Hz}, 1 \mathrm{H}\right.$, aromatic), $7.29-7.39\left(\mathrm{~m}, 2 \mathrm{H}\right.$, aromatic), $8.06\left(\mathrm{~d},{ }^{3} J_{\mathrm{H}, \mathrm{H}}=8.2 \mathrm{~Hz}\right.$, $1 \mathrm{H}$, aromatic), $8.76\left(\mathrm{~d},{ }^{3} \mathrm{~J}_{\mathrm{H}, \mathrm{H}}=3.6 \mathrm{~Hz}, 1 \mathrm{H}\right.$, aromatic); ${ }^{13} \mathrm{C}\left\{{ }^{1} \mathrm{H}\right\}-\mathrm{NMR}\left(\mathrm{CDCl}_{3} ; 100.6 \mathrm{MHz}\right) \delta=$ $109.9,115.9,121.4,127.2,128.8,135.9,138.5,143.9,147.4$.

4-Chloroquinolin-8-amine (6b) [24] as a yellow solid $3.3 \mathrm{~g}(18.8 \mathrm{mmol}, 75 \%) ; \mathrm{mp}=90-95$

${ }^{\circ} \mathrm{C} ;{ }^{1} \mathrm{H}-\mathrm{NMR}\left(\mathrm{CDCl}_{3} ; 400.2 \mathrm{MHz}\right) \delta=4.94\left(\mathrm{bs}, 2 \mathrm{H}, \mathrm{NH}_{2}\right), 6.95\left(\mathrm{~d},{ }^{3} \mathrm{~J}_{\mathrm{H}, \mathrm{H}}=7.5 \mathrm{~Hz}, 1 \mathrm{H}\right.$, aromatic), $7.40\left(\mathrm{t},{ }^{3} J_{\mathrm{H}, \mathrm{H}}=8.0 \mathrm{~Hz}, 1 \mathrm{H}\right.$, aromatic), $7.44\left(\mathrm{~d},{ }^{3} J_{\mathrm{H}, \mathrm{H}}=4.6 \mathrm{~Hz}, 1 \mathrm{H}\right.$, aromatic), 7.51 $\left(\mathrm{dd},{ }^{3} J_{\mathrm{H}, \mathrm{H}}=8.4 \mathrm{~Hz},{ }^{4} J_{\mathrm{H}, \mathrm{H}}=0.6 \mathrm{~Hz}, 1 \mathrm{H}\right.$, aromatic), $8.59\left(\mathrm{~d},{ }^{3} J_{\mathrm{H}, \mathrm{H}}=4.6 \mathrm{~Hz}, 1 \mathrm{H}\right.$, aromatic); ${ }^{13} \mathrm{C}\left\{{ }^{1} \mathrm{H}\right\}-\mathrm{NMR}\left(\mathrm{CDCl}_{3} ; 100.6 \mathrm{MHz}\right) \delta=110.9,112.1,121.5,127.2,128.5,139.0,142.6,144.3$, 146.4; GC-MS: $\mathrm{t}_{\mathrm{r}}=6.3 \mathrm{~min}$, (EI) $\mathrm{M}^{+}=178(100 \%)$; UV-Vis (methanol; $\left.\lambda(\mathrm{nm})(\log \varepsilon)\right): 363$ (3.80), 340 (3.84), 291 (3.45), 253 (4.71), 207 (4.76); IR (KBr): $v=3426,3285,1620,1501,1358$, $808,743 \mathrm{~cm}^{-1}$.

8-(tert-Butyl)-2-methylquinolin-5-amine (6c) as a brown solid, $2.7 \mathrm{~g}(12.8 \mathrm{mmol}, 51 \%)$; mp.dec. $=90.1-90.3{ }^{\circ} \mathrm{C} ;{ }^{1} \mathrm{H}$ NMR $\left(\mathrm{CDCl}_{3} ; 500.2 \mathrm{MHz}\right) \delta=1.63\left(\mathrm{~s}, 9 \mathrm{H}, \mathrm{C}\left(\mathrm{CH}_{3}\right)_{3}\right), 2.70(\mathrm{~s}$, $\left.3 \mathrm{H}, \mathrm{CH}_{3}\right), 3.96\left(\mathrm{~s}, 2 \mathrm{H}, \mathrm{NH}_{2}\right), 6.65\left(\mathrm{~d}^{3}{ }^{3} \mathrm{~J}_{\mathrm{H}, \mathrm{H}}=7.9 \mathrm{~Hz}, 1 \mathrm{H}\right.$, aromatic $), 7.16\left(\mathrm{~d}^{3} J_{\mathrm{H}, \mathrm{H}}=8.6 \mathrm{~Hz}\right.$, $1 \mathrm{H}$, aromatic), $7.40\left(\mathrm{~d}^{3} \mathrm{~J}_{\mathrm{H}, \mathrm{H}}=7.9 \mathrm{~Hz}, 1 \mathrm{H}\right.$, aromatic), $8.00\left(\mathrm{~d},{ }^{3} \mathrm{~J}_{\mathrm{H}, \mathrm{H}}=8.6 \mathrm{~Hz}, 1 \mathrm{H}\right.$, aromatic); ${ }^{13} \mathrm{C}\left\{{ }^{1} \mathrm{H}\right\}-\mathrm{NMR}\left(\mathrm{CDCl}_{3} ; 125.8 \mathrm{MHz}\right) \delta=25.4,31.2,35.9,108.9,117.9,119.2,126.1,129.5,138.4$, 140.4, 147.4, 155.4; MS (ES-TOF): $m / z$ (rel. int.) $(\mathrm{M}+\mathrm{H})^{+}=215.1550(100 \%)$; HRMS (ESTOF): $m / z$ Calcd for $\mathrm{C}_{14} \mathrm{H}_{19} \mathrm{~N}_{2}(\mathrm{M}+\mathrm{H})^{+}=215.1548$, Found 215.1550; UV-Vis (methanol; $\lambda$ $(\mathrm{nm})(\log \varepsilon)): 336(3.82), 252$ (4.67), 204 (4.73); IR (KBr): $v=3363,2940,1663,1609,1356,823$, $789 \mathrm{~cm}^{-1}$; Anal. Calcd for $\mathrm{C}_{14} \mathrm{H}_{18} \mathrm{~N}_{2}: \mathrm{C}, 78.46 ; \mathrm{H}, 8.47 ; \mathrm{N}, 13.07$; Found: $\mathrm{C}, 78.65 ; \mathrm{H}, 8.49$; $\mathrm{N}, 12.94$.

8-(iso-Propyl)-2-methylquinolin-5-amine (6d) as a red liquid, $4.3 \mathrm{~g}(21.5 \mathrm{mmol}, 86 \%)$; bp 110-115 ${ }^{\circ} \mathrm{C} / 5 \mathrm{~mm} \mathrm{Hg} ;{ }^{1} \mathrm{H}-\mathrm{NMR}\left(\mathrm{CDCl}_{3} ; 400.2 \mathrm{MHz}\right) \delta=1.32\left(\mathrm{~d},{ }^{3} \mathrm{~J}_{\mathrm{H}, \mathrm{H}}=7.0 \mathrm{~Hz}, 6 \mathrm{H}\right.$, $\left.\mathrm{CH}\left(\mathrm{CH}_{3}\right)_{2}\right), 2.69\left(\mathrm{~s}, 3 \mathrm{H}, \mathrm{CH}_{3}\right), 3.92\left(\mathrm{bs}, 2 \mathrm{H}, \mathrm{NH}_{2}\right), 4.25$ (septet, $\left.{ }^{3} \mathrm{~J}_{\mathrm{H}, \mathrm{H}}=6.9 \mathrm{~Hz}, 1 \mathrm{H}, \mathrm{CH}\right), 6.68$ $\left(\mathrm{d}^{3} \mathrm{~J}_{\mathrm{H}, \mathrm{H}}=7.8 \mathrm{~Hz}, 1 \mathrm{H}\right.$, aromatic), $7.13\left(\mathrm{~d}^{3} \mathrm{~J}_{\mathrm{H}, \mathrm{H}}=8.6 \mathrm{~Hz}, 1 \mathrm{H}\right.$, aromatic $), 7.33\left(\mathrm{~d}^{3} J_{\mathrm{H}, \mathrm{H}}=7.8\right.$ $\mathrm{Hz}, 1 \mathrm{H}$, aromatic), $7.96\left(\mathrm{~d}^{3} \mathrm{~J}_{\mathrm{H}, \mathrm{H}}=8.6 \mathrm{~Hz}, 1 \mathrm{H}\right.$, aromatic); $\left.{ }^{13} \mathrm{C}^{1}{ }^{1} \mathrm{H}\right\}-\mathrm{NMR}\left(\mathrm{CDCl}_{3} ; 125.8 \mathrm{MHz}\right)$ $\delta=23.7,25.5,26.6,109.5,117.0,119.9,125.3,129.7,137.4,139.8,146.1,157.2 ;$ MS (ES-TOF): $m / z$ (rel. int.) $(\mathrm{M}+\mathrm{H})^{+}=201.1393(100 \%)$; HRMS (ES-TOF): $m / z$ Calcd for $\mathrm{C}_{13} \mathrm{H}_{17} \mathrm{~N}_{2}(\mathrm{M}+$ $\mathrm{H})^{+}=201.1392$, Found 201.1393; UV-Vis (methanol; $\left.\lambda(\mathrm{nm})(\log \varepsilon)\right): 340(3.46), 253(4.41)$, 202 (4.44); Anal. Calcd for $\mathrm{C}_{13} \mathrm{H}_{16} \mathrm{~N}_{2}$ : C, 77.96; H, 8.05; N, 13.99; Found: C, 77.60; H, 8.09; $\mathrm{N}, 13.86$.

\section{Conclusions}

In this research, the synthesis of four new VNS substitution products and 8-nitroquinoline derivatives was presented. Two of these i.e., molecules $\mathbf{5 a}$ and $\mathbf{5 b}$, illustrate the nitro/nitroso conversion within VNS substitution. Additionally, 9-(8-isopropyl-2-((8-isopropyl2-methyl-5-nitroquinolin-6-yl)methyl)-5-nitrosoquinolin-6-yl)-9H-carbazole was presented 
as a double-VNS product. Our results showed that direct nucleophilic displacement of an aromatic hydrogen reaction proceeded together with expected $\mathrm{S}_{\mathrm{N}} \mathrm{Ar}$ of chloride located in activated $\mathrm{C} 4$ position. Our findings show exclusively one product type, with a newly formed C7-N or C6-N bond in ortho-position to nitro group. Other regioisomers, especially in para-position, were not observed, which suggests the dominant role of the potassium cation in contributing attractive interaction to tight ion-pairs with the oxygen on nitro group. Additionally, a reduction of nitroquinoline derivatives by stannous chloride crystal as an effective and predictable reaction, tolerating other functional groups, was observed.

Supplementary Materials: The following are available online, CCDC 1967406 for 4b, CCDC 2048040 for 4c, CCDC 2048038 for 5a and CCDC 2048039 for 5b contains the supplementary crystallographic data for this paper. These data can be obtained free of charge from http://www.ccdc.cam.ac. uk/conts/retrieving.html, or from the Cambridge Crystallographic Data Centre, 12 Union Road, Cambridge CB2 1EZ, UK; fax: (+44) 1223-336-033; or e-mail: deposit@ccdc.cam.ac.uk. Calculations have been carried out in Wroclaw Centre for Networking and Supercomputing (http:/ / www.wcss. wroc.pl). The following are available online, Tables S1-S3 selected bond lengths for molecules $4 \mathbf{b}, 4 \mathbf{c}$, 5a and 5b, Figures S1-S12: ${ }^{1} \mathrm{H}-\mathrm{NMR},{ }^{13} \mathrm{C}-\mathrm{NMR}, \mathrm{HMQC}$ and MS spectra.

Author Contributions: J.W., D.S., J.E.N. and V.K. performed the experiments; M.K., J.K. and J.G.M. X-ray measurements and diffraction data analysis; J.W. theoretical calculations (DFT); J.W. IR and UV-Vis measurements; J.E.N. designed and analyzed the data; J.E.N. and J.W. wrote and edited manuscript. All authors have read and agreed to the published version of the manuscript.

Funding: This research received no external funding.

Data Availability Statement: Data set presented in this study is available in this article.

Acknowledgments: We thank the Mobility Supporting Fund of Faculty of Pharmacy, Charles University Prague for the 3 months award to stay at Institute of Chemistry, University of Silesia in Katowice, Katowice, Poland to Vladimír Kubíček.

Conflicts of Interest: The authors declare no conflict of interest.

\section{References}

1. Collin, G.; Höke, H. Quinoline and Isoquinoline. In Ullmann's Encyclopedia of Industrial Chemistry; Wiley-VCH: Weinheim, Germany, 2003.

2. Nycz, J.E.; Wantulok, J.; Sokolova, R.; Pajchel, L.; Stankevič, M.; Szala, M.; Malecki, J.G.; Swoboda, D. Synthesis and Electrochemical and Spectroscopic Characterization of 4,7-diamino-1,10-phenanthrolines and Their Precursors. Molecules 2019, $24,4102$. [CrossRef] [PubMed]

3. Makosza, M.; Winiarski, J. Vicarious nucleophilic substitution of hydrogen. Acc. Chem. Res. 1987, 20, 282-289. [CrossRef]

4. Małecki, J.G.; Maroń, A.; Palion, J.; Nycz, J.E.; Szala, M. A copper(I) phosphine complex with 5,7-dinitro-2-methylquinolin-8-ol as co-ligand. Transit. Met. Chem. 2014, 39, 755-762. [CrossRef]

5. Lawrence, N.J.; Lamarche, O.; Thurrab, N. The facile synthesis of $\alpha$-aryl- $\alpha$-hydroxy esters via one-pot vicarious nucleophilic substitution and oxidation. Chem. Commun. 1999, 689-690. [CrossRef]

6. Mąkosza, M.; Staliński, K. Oxidative Nueleophilie Substitution of Hydrogen in Nitroarenes with Phenylacetonitrile Derivatives. Tetrahedron 1998, 54, 8797-8810. [CrossRef]

7. Le Manach, C.; Paquet, T.; Wicht, K.J.; Nchinda, A.T.; Brunschwig, C.; Njoroge, M.; Gibhard, L.; Taylor, D.; Lawrence, N.; Wittlin, S.; et al. Antimalarial Lead-Optimization Studies on a 2,6-Imidazopyridine Series within a Constrained Chemical Space to Circumvent Atypical Dose-Response Curves against Multidrug Resistant Parasite Strains. J. Med. Chem. 2018, 61, 9371-9385. [CrossRef]

8. Müller, A.V.; Ramos, L.D.; Frin, K.P.M.; De Oliveira, K.T.; Polo, A.S. A high efficiency ruthenium(ii) tris-heteroleptic dye containing 4,7-dicarbazole-1,10-phenanthroline for nanocrystalline solar cells. RSC Adv. 2016, 6, 46487-46494. [CrossRef]

9. Szpakiewicz, B.; Grzegożek, M. Vicarious nucleophilic amination of nitroquinolines with 4-amino-1,2,4-triazole. Can. J. Chem. 2008, 86, 682-685. [CrossRef]

10. Bocharova, E.A.; Gornostaev, L.M.; Gritsan, N.P.; Gurova, T.N. Amination of 3,5-dibromo-4-nitrosoanilines and 3-halo-4nitrosophenols. Russ. J. Org. Chem. 2010, 46, 1639-1644. [CrossRef]

11. Nicholls, A.J.; Batsanov, A.S.; Baxendale, I.R. Copper-Mediated Nitrosation: 2-Nitrosophenolato Complexes and Their Use in the Synthesis of Heterocycles. Molecules 2019, 24, 4154. [CrossRef] 
12. Malecki, G.; Nycz, J.E.; Ryrych, E.; Ponikiewski, L.; Nowak, M.; Kusz, J.; Pikies, J. Synthesis, spectroscopy and computational studies of some biologically important hydroxyhaloquinolines and their novel derivatives. J. Mol. Struct. 2010, 969, 130-138. [CrossRef]

13. Szala, M.; Nycz, J.E.; Malecki, G.J.; Sokolova, R.; Ramesova, S.; Switlicka-Olszewska, A.; Strzelczyk, R.; Podsiadly, R.; Machura, B. Synthesis of 5-azo-8-hydroxy-2-methylquinoline dyes and relevant spectroscopic, electrochemical and computational studies. Dye. Pigment. 2017, 142, 277-292. [CrossRef]

14. CrysAlisPro 1.171.38.43 (Rigaku Oxford Diffraction, 2015). Available online: https://www.rigaku.com/en/products/smc/ crysalis (accessed on 20 December 2020).

15. Dolomanov, O.V.; Bourhis, L.J.; Gildea, R.J.; Howard, J.A.K.; Puschmann, H. OLEX2: A complete structure solution, refinement and analysis program. J. Appl. Crystallogr. 2009, 42, 339-341. [CrossRef]

16. Sheldrick, G.M. A short history of SHELX. Acta Cryst. 2008, A64, 112-122. [CrossRef] [PubMed]

17. Nycz, J.E.; Malecki, G.J. Synthesis, spectroscopy and computational studies of selected hydroxyquinoline carboxylic acids and their selected fluoro-, thio-, and dithioanalogues. J. Mol. Struct. 2013, 1032, 159-168. [CrossRef]

18. Vierhapper, F.W.; Eliel, E.L.; Zuniga, G. Carbon-13 spectra of saturated heterocycles. 10. Effect of lone electron pairs on nitrogen on the chemical shift of antiperiplanar vicinal methyl carbons. J. Org. Chem. 1980, 45, 4844-4850. [CrossRef]

19. Prema, D.; Wiznycia, A.V.; Scott, B.M.T.; Hilborn, J.; Desper, J.; Levy, C.J. Dinuclear Zinc(II) complexes of symmetric Schiff-base ligands with extended quinoline sidearms. Dalton Trans. 2007, 4788-4796. [CrossRef] [PubMed]

20. Sen, C.; Sahoo, T.; Singh, H.; Suresh, E.; Ghosh, S.C. Visible Light-Promoted Photocatalytic C-5 Carboxylation of 8-Aminoquinoline Amides and Sulfonamides via a Single Electron Transfer Pathway. J. Org. Chem. 2019, 84, 9869-9896. [CrossRef] [PubMed]

21. Darque, A.; Dumètre, A.; Hutter, S.; Casano, G.; Robin, M.; Pannecouque, C.; Azas, N. Synthesis and biological evaluation of new heterocyclic quinolinones as anti-parasite and anti-HIV drug candidates. Bioorg. Med. Chem. Lett. 2009, 19, 5962-5964. [CrossRef] [PubMed]

22. Todorov, A.R.; Aikonen, S.; Muuronen, M.; Helaja, J. Visible-Light-Photocatalyzed Reductions of N-Heterocyclic Nitroaryls to Anilines Utilizing Ascorbic Acid Reductant. Org. Lett. 2019, 21, 3764-3768. [CrossRef]

23. Saggadi, H.; Luart, D.; Thiebault, N.; Polaert, I.; Estel, L.; Len, C. Quinoline and phenanthroline preparation starting from glycerol via improved microwave-assisted modified Skraup reaction. RSC Adv. 2014, 4, 21456-21464. [CrossRef]

24. Ding, D.; Jiang, H.; Ma, X.; Nash, J.J.; Kenttämaa, H.I. Effects of the Distance between Radical Sites on the Reactivities of Aromatic Biradicals. J. Org. Chem. 2020, 85, 8415-8428. [CrossRef] [PubMed]

Sample Availability: Samples of the compounds are available on request from the corresponding authors. 